\title{
Cannabinomimetric Lipids: From Natural Extract to Artificial Synthesis
}

\author{
Ya-Ru Gao'· Yong-Qiang Wang ${ }^{1}$
}

Received: 30 October 2017 / Accepted: 28 December 2017/Published online: 16 January 2018

(C) The Author(s) 2018. This article is an open access publication

\begin{abstract}
Endocannabinoid system is related with various physiological and cognitive processes including fertility, pregnancy, during pre- and postnatal development, pain-sensation, mood, appetite, and memory. In the latest decades, an important milestone concerning the endocannabinoid system was the discovery of the existence of the cannabinoid receptors $\mathrm{CB}_{1}$ and $\mathrm{CB}_{2}$. Anandamide was the first reported endogenous metabolite, which adjusted the release of some neurotransmitters through binding to the $\mathrm{CB}_{1}$ or $\mathrm{CB}_{2}$ receptors. Then a series of cannabinomimetric lipids were extracted from marine organisms, which possessed similar structure with anandamide. This review will provide a short account about cannabinomimetric lipids for their extraction and synthesis.
\end{abstract}

Keywords Endocannabinoid · Cannabinoid receptors · Cannabinomimetric lipids

$\begin{array}{ll}\text { Abbreviations } \\ m \text {-CPBA } & \text { 3-Chloroperbenzoic acid } \\ \text { DCC } & \text { Dicyclohexylcarbodiimide } \\ \text { DDQ } & \text { 2, 3-Dicyano-5,6-dichlorobenzoquinone } \\ \text { PMB } & \text { p-Methoxybenzyl } \\ \text { IBX } & \text { 2-Iodoxybenzoic acid } \\ \text { TBDPS } & \text { tert-Butyldiphenylsilyl } \\ \text { TBAF } & \text { Tetrabutylammonium fluoride } \\ \text { TFA } & \text { Trifluoroacetic acid } \\ \text { MOMCl } & \text { Chloromethyl methyl ether } \\ \text { HMPA } & \text { Hexamethylphosphoramide } \\ \text { PDC } & \text { Pyridinium dichlorochromate } \\ \text { EDA } & \text { 1-Ethyl-3-(3- } \\ & \text { dimethylaminopropy)carbodiimide }\end{array}$

\section{Introduction}

In the past decades, pharmacologists devoted more interest to the study of endocannabinoid system due to its relation with various physiological and cognitive processes including fertility, pregnancy, during pre- and postnatal

Yong-Qiang Wang

wangyq@nwu.edu.cn

1 Key Laboratory of Synthetic and Natural Functional Molecule Chemistry of Ministry of Education, Department of Chemistry \& Materials Science, Northwest University, Xi' an 710069, People's Republic of China development, pain-sensation, mood, appetite, and memory [1]. Originally, the endocannabinoid system was discovered while scientists tried to understand the physical and psychological effects of cannabis, thereby named it the endocannabinoid system for this reason. An important milestone concerning the endocannabinoid system was the discovery of the existence of the cannabinoid receptors $\left(\mathrm{CB}_{1}\right.$ and $\left.\mathrm{CB}_{2}\right)$ in central and peripheral mammalian tissues [2-5]. Both receptors $\mathrm{CB}_{1}$ and $\mathrm{CB}_{2}$ belong to the large family of G-protein-coupled receptors (GPCR). $\mathrm{CB}_{1}$ receptor exhibits a widespread distribution in the mammalian brain and are responsible for the psychological and anticonvulsive effects produced by marijuana [2-5], while $\mathrm{CB}_{2}$ receptor is most abundant in the immune and hematopoietic system and is involved in the anti-inflammatory and possibly other therapeutic effects of cannabis $[4,5]$. The discovery of cannabinoid receptors $\left(\mathrm{CB}_{1}\right.$ and $\mathrm{CB}_{2}$ ) has launched the quest for endogenous ligands of these receptors. Based on the assumption that the endogenous cannabinoid ligand was a lipid soluble compound, a lipid derivative was first isolated from chloroform-methanol extracts of porcine brain and christened anandamide by Mechoulam et al. in 1992 (Fig. 1) [6]. This endogenous metabolite bound to both $\mathrm{CB}_{1}$ and $\mathrm{CB}_{2}$ receptors and was found in nearly all tissues in a wide range of animals [7]. Then a series of alkyl amides were extracted from marine organisms, which resembled structurally some aspects of anandamide and had been termed cannabimimetic lipids. In the biological activity tests, they showed the ability to bind and activate at least one 


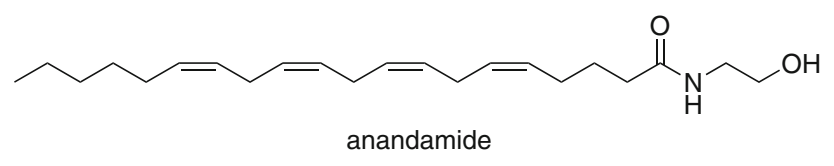

Fig. 1 The structure of anandamide

cannabinoid receptor [8]. This review will provide a short account of cannabinomimetric lipids for their natural extract and artificial synthesis.

\section{Extraction and Biological Activities (Fig. 2)}

\subsection{Grenadamide}

Grenadamide was isolated from the organic extract of a Grenada collection of the marine cyanobacterium Lyngbya majuscula by Gerwick et al. in 1998. It exhibited brine shrimp toxicity $\left(\mathrm{LD}_{50}=5 \mu \mathrm{g} / \mathrm{mL}\right)$ and modest cannabinoid receptor binding activity $\left(K_{i}=4.7 \mu \mathrm{M}\right)$ [9]. Gerwick et al. verified the structure and the relative stereochemistry of grenadamide, which was a trans-cyclopropyl-containing fatty acid-derived metabolite.

\subsection{Mooreamide A}

Mooreamide A was extracted from cyanobacterium Moorea bouillonii by Gerwick et al. from Papua New Guinea, and showed strong and selective affinity to $\mathrm{CB}_{1}$ ligand [10].

\subsection{Serinolamides}

Serinolamide A was isolated from marine cyanobacteria Lyngbya majuscule collected in Papua New Guineal. It displayed a moderate agonist effect and selectivity for the $\mathrm{CB}_{1}$ cannabinoid receptor [11]. Serinolamide B, a closely related analogue of serinolamide $\mathrm{A}$, was isolated from a Lyngbya sample from the piti Bomb Holes in Guam by Luesch et al. [12]. It showed moderate affinities to both $\mathrm{CB}_{1}$ and $\mathrm{CB}_{2}$, while exhibited a higher selectivity for $\mathrm{CB}_{2}$ $\left(K_{i}=5.2 \mu \mathrm{m}\right)$ over $\mathrm{CB}_{1}\left(K_{i}=16.4 \mu \mathrm{m}\right)$

\subsection{Semiplenamides}

Semiplenamides A to $\mathrm{G}$ were isolated from the marine cyanobacterium Lyngbya semiplena collected from Papua New Guinea by Gerwick et al. [13]. In the test of their affinity to cannabinoid receptors of the rat brain membranes, only semiplenamides $\mathrm{A}, \mathrm{B}$ and $\mathrm{G}$ worked. In the test of fatty acid amide hydrolase (FAAH), the semiplenamides $A$ to $G$ were not found appreciable inhibitory effect.

\subsection{Malyngamides}

Malyngamides include over 30 members, characterized by different $N$-substitution groups of amides. They were isolated from Marine cyanobacterium Lyngbya majuscule, and showed a wide range of biological activities, such as antifeedant activity, ichthyotoxicity, toxicity to other marine animals, cytotoxicity to cancer cells, anti-HIV, antileukemic, and anti-tumor activity [14-16]. The finding that malyngamide B possesses cannabimimetic properties provides new insight into the biological activities of malyngamides. The extraction information of malyngamides was illustrated in Table 1.

Hermitamides resemble the malyngamide-type compound in structure and were still isolated from the marine marine cyanobacterium L. majuscula of other species of Gracilaria [17-19]. Hermitamides were evaluated for their biological activity in several systems. Hermitamides A (1) and $\mathrm{B}$ (2) showed $\mathrm{LD}_{50}$ values of $5 \mu \mathrm{M}$ and $18 \mu \mathrm{M}$ respectively in the brine shrimp (Artemia salina) toxicity assay, and showed $\mathrm{IC}_{50}$ values of $2.2 \mu \mathrm{M}$ and $5.5 \mu \mathrm{M}$ respectively to Neuro-2a neuroblastoma cells in tissue culture.

\section{Synthesis of Cannabinomimetric Lipids}

\subsection{Synthesis of Grenadamide}

In 2004, Baird and co-workers reported the synthesis of grenadamide and confirmed its absolute stereochemistry (Scheme 1) [9]. The synthesis started from the aldehyde 1, which was converted to olefin 2 through Wittig reaction the following ester hydrolysis. Then removal of the double bond gave $\mathbf{3}$. Oxidation of alcohol $\mathbf{3}$ got aldehyde $\mathbf{4}$ and epimerisation of $\mathbf{4}$ using sodium methoxide in methanol afforded the epimer $\mathbf{5}$. Then $\mathbf{5}$ underwent HWE reaction with ethoxycarbonyl triphenylphosphosphorane to give the ester 6, which was removed the double bond with dipotassium azodicarboxylate and hydrolysed with $\mathrm{KOH}$ to afford acid 7. The compound 7 was converted into the corresponding chloride, then treated with 2-phenylethylamine to give the amide $\mathbf{8}$, which had an equal and opposite absolute rotation compared with natural grenadamide. So the synthetic sample was the enantiomer of the natural product grenadamide.

One year later, Bull and co-workers reported an asymmetric synthesis of grenadamide in 6 steps using $(R)-5,5$ dimethyl-oxa-zolidin-2-one as a chiral auxiliary (Scheme 2) [46]. The starting material 9 as a chiral auxiliary was acetylated with chloroacetyl chloride to give $\mathbf{1 0}$. Then treatment of $\mathbf{1 0}$ with 9-BBN-OTf and $i-\mathrm{Pr}_{2} \mathrm{NEt}$ and 


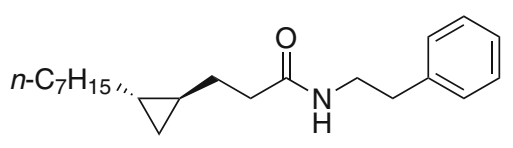

grenadamide<smiles>C=CC(=O)NC(CO)CO</smiles>

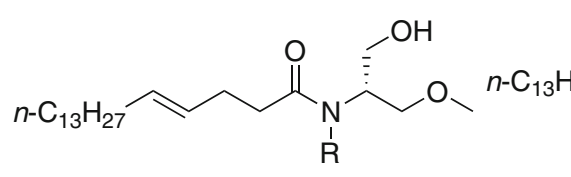

serinolamide $A \quad R=M e$ serinolamide $B \quad R=H$

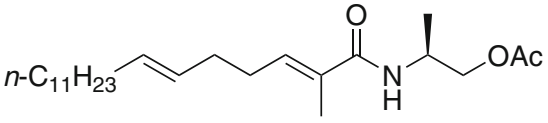

semiplenamide $\mathrm{E}$<smiles>CC=C(C)C(=O)N[C@@H](C)CO</smiles>
semiplenamide $C$<smiles>CC(=O)OC[C@H](C)NC(=O)/C(C)=C/CC/C=C/[13CH]C(=O)O</smiles>
semiplenamide D mooreamide $\mathrm{A}$

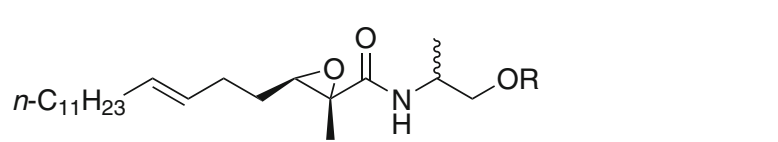

$\mathrm{R}=\mathrm{H}$ semiplenamide $\mathrm{F}$ $\mathrm{R}=\mathrm{H}$ semiplenamide $\mathrm{G}$<smiles>[R]N(CC)C(=O)CC/C=C/C[C@H](CCCCCCC)OC</smiles><smiles>CCC/C(=C/Cl)C/C(=C\C(=O)N1CC(OC)=CC1=O)COC</smiles>

$\mathrm{R}^{\prime}=\mathrm{CH}_{3}$ malyngamide $\mathrm{A}$<smiles>[Y6]CC(=CCl)CC(=CC(=O)N1CC(O)CC1=O)OC</smiles>

$\mathrm{R}^{\prime}=\mathrm{CH}_{3}$ malyngamide $B$

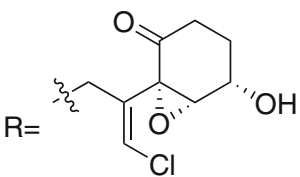

$\mathrm{R}^{\prime}=\mathrm{H}$ malyngamide $\mathrm{C}$<smiles>COC[C@H](C=[P])[C@H](O)[C@H]1C(=O)C(C)(C)C(O)C(C)C1O</smiles>
$\mathrm{R}^{\prime}=\mathrm{H}$ malyngamide D<smiles>[Y6]C(COC)C(O)C1=CC(C)C(O)C(C)(C)C1=O</smiles>

$\mathrm{R}^{\prime}=\mathrm{H}$ malyngamide $\mathrm{E}$

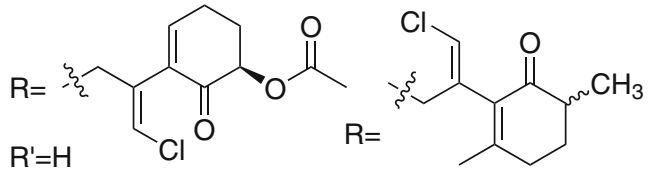

$\mathrm{R}^{\prime}=\mathrm{H}$ malyngamide $\mathrm{G}$<smiles>[Y9]CCC(=C)C12O[C@@H]1CC=C(C)C2=O</smiles>

$\mathrm{R}^{\prime}=\mathrm{H}$

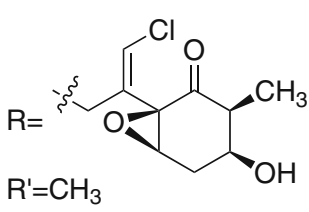

malyngamide I

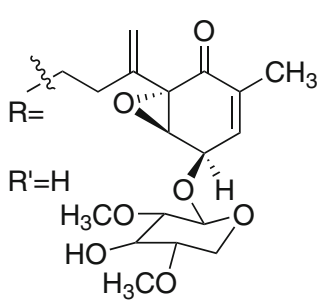

malyngamide $\mathrm{J}$<smiles>[R][R]([R])([H])C(=CCl)C1=CCCCC1=O</smiles>

$\mathrm{R}^{\prime}=\mathrm{H}$

malyngamide $\mathrm{K}$

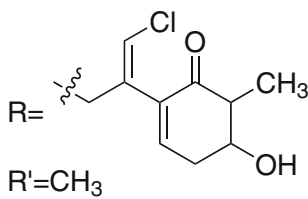

malyngamide $\mathrm{L}$<smiles>[2H]C(C)([18F])C/C(=C/Cl)c1cccc(C)c1O</smiles>

malyngamide $\mathrm{M}$

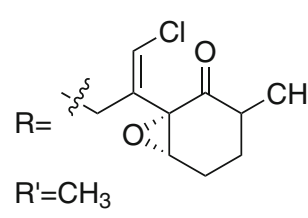

malyngamide $\mathrm{N}$<smiles>[Y9]CC(=CCl)CC(CC(=O)OC)OC</smiles>

malyngamide $\mathrm{O}$

malyngamide $P$

Fig. 2 The structures of cannabinomimetric lipids 
<smiles>[R7]CCC(=CCl)Cc1cc(OC)cc(=O)o1</smiles>

$\mathrm{R}^{\prime}=\mathrm{H}$ malyngamide $Q$

$\mathrm{R}^{\prime}=\mathrm{CH}_{3}$ malyngamide $\mathrm{R}$

malyngamide S malyngamide $T$<smiles>[R]P(C)(=O)C[C@H](OC)[C@H]1C(=O)C(C)=CC[C@H]1O</smiles>

malyngamide $U$<smiles>[R]PC(C)(C)C[C@H](OC)[C@@H]1C(=O)C(C)=CC[C@H]1O</smiles>

malyngamide $\mathrm{V}$

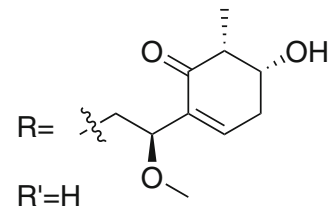

malyngamide $\mathrm{W}$<smiles>[R]P=CCC(=CCl)C1=CCCC(C)C1=O</smiles>

malyngamide $\mathrm{Y}$<smiles>C[C@]1(O)[C@H](O)C[C@@H](O)C(=O)[C@@H]1/C(Cl)=C/C=P</smiles><smiles>CCC(=CCl)CC(=O)CC(=O)NC[C@H](O)CC(=O)OC</smiles><smiles>C=[13CH]CC(=CCl)C/C(=C\C(=O)N1CCCC1=O)COC</smiles><smiles>C=PCCCCCCCCCCCCCCCC(=CCl)CC(=CC(=O)N1CC(OC)=CC1=O)OC</smiles>
malyngamide 3

malyngamide 4

$\mathrm{OH}$<smiles>O=C1CC[C@@H](O)[C@H](O)[C]1/C(=C\Cl)CCP</smiles>

$\mathrm{R}^{\prime}=\mathrm{H}$<smiles>[R][Y]([H])([H])C(=CCl)C1=CCCCC1=O</smiles>

$\mathrm{R}^{\prime}=\mathrm{H}$

8-epi-malyngamide C 2Z-isomalyngamide K

2Z-isomalyngamide A 2Z-isomalyngamide B

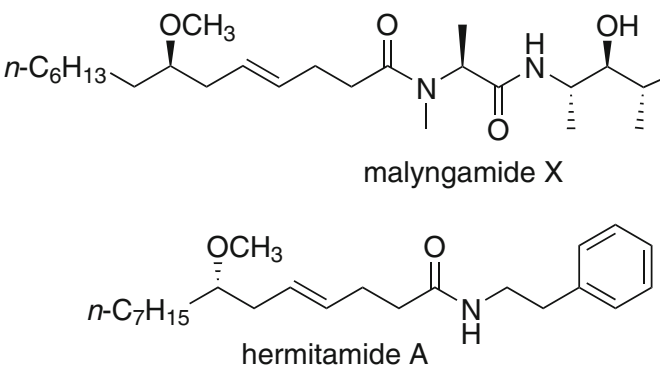<smiles>CC(C)C1C(=O)C=CC1=O</smiles><smiles>COCCCCCCCCCCCCCCC(=O)NC(COC)COC</smiles>
serinol-malyngamide<smiles>CC[C@H](CC=CCCC(=O)NCCC1=CNC2C=CC=CC12)OC</smiles>

Fig. 2 continued

following reaction with $\alpha, \beta$-unsaturated aldehyde afforded syn-aldol product $\mathbf{1 1}$ in $92 \%$ de. Cyclopropanation of $\mathbf{1 1}$ with $\mathrm{Et}_{2} \mathrm{Zn}$ and $\mathrm{CH}_{2} \mathrm{I}_{2}$ afforded 12 with high stereoselectivity. Then replacing the oxazolidin-2-one fragment with phenylethylamine gave 13, which was treated with $\mathrm{SmI}_{2}$ resulted in clean elimination reactions to afford $(E)-\alpha, \beta$ unsaturated amide. Finally reduction of the double bond with $\mathrm{NaBH}_{4}$ and $\mathrm{CoCl}_{2}$ afford grenadamide.
In the same year, Taylor and co-workers reported the total synthesis of both (+)-grenadamide and (-)-grenadamide by a racemic route (Scheme 3) [47]. Wittig reaction of 4-methoxycinnamaldehyde $\mathbf{1 5}$ and octyltriphenylphosphonium iodide resulted the 1,3-diene $\mathbf{1 6}$. Then photolysis of 1,3-diene $\mathbf{1 6}$ gave the 1,2-dioxine 17, which reacted with tert-butyl ester ylide to afford cyclopropane 18. Then hydrolysis of tert-butyl ester group with formic acid gave acid 19, which was subsequently decarboxylated using the 
Table 1 The extraction of Malyngamides

\begin{tabular}{|c|c|c|}
\hline Malyngamides & Source & Reference \\
\hline Malyngamide A & Marine cyanophyte Lyngbya majuscula & Cardellina II et al. [20] \\
\hline Malyngamide B & Blue-green alga Lyngbya majuscule & Cardellina II et al. [21] \\
\hline Malyngamide C & $\begin{array}{l}\text { Shallow-water variety of Lyngbya majuscula found on the reefs of Fanning Island in the } \\
\text { Line Islands }\end{array}$ & Ainslie et al. [22] \\
\hline Malyngamides D, E & Deep water variety of the marine cyanophyte Lyngbya majuscula & Mynderse et al. $[23,24]$ \\
\hline Malyngamides F & Cyanobacterium Lyngbya majuscula & Villa et al. [25] \\
\hline Malyngamide G & Blue-green alga epiphyte of the brown mediterranean alga Cystoseira crinita & Praud et al. [26] \\
\hline Malyngamide $\mathrm{H}$ & Tropical marine cyanobacteriurn Lyngbya mjuscula & Orjala et al. [27] \\
\hline Malyngamide I & $\begin{array}{l}\text { Tropical marine cyanobacterium Lyngbya } \\
\text { majuscula }\end{array}$ & Todd et al. [28] \\
\hline Malynsamides J, K, L & Marine cyanobaeterium Lyngbya majuscula & Wu et al. [29] \\
\hline Malyngamide $\mathrm{M}, \mathrm{N}$ & Hawaiian red alga Gracilaria coronopifolia & Kan et al. [30] \\
\hline Malyngamides $\mathrm{O}, \mathrm{P}$ & Sea hare Stylocheilus longicauda & Gallimore et al. [31] \\
\hline Malyngamides Q, R & Madagascan Lyngbya majuscula & Milligan et al. [32] \\
\hline Malyngamides S & New Zealand collection of the sea hare Bursatella leachii & Appleton et al. [33] \\
\hline Malyngamides T & Puerto Rican collection of Lyngbya majuscula & Nogle et al. [34] \\
\hline Malyngamides U, V, W & Marine cyanobacterium Lyngbya majuscula collected in Papua New Guinea & McPhail et al. [35] \\
\hline Malyngamide X & Thai sea hare Bursatella leachii & $\begin{array}{l}\text { Suntornchashwej et al. } \\
\text { [36] }\end{array}$ \\
\hline Malyngamide Y & a Florida collection of Moorea producens & Sabry et al. [37] \\
\hline Malyngamide 2 & marine cyanobacterium cf. Lyngbya sordida & Malloy et al. [38] \\
\hline Malyngamide 3 & Lyngbya majuscula from Cocos Lagoon, Guam & Gunasekera et al. [39] \\
\hline Malyngamide 4 & Red Sea marine cyanobacterium Moorea producens & Shaala et al. [40] \\
\hline Isomalyngamides $\mathrm{A}, \mathrm{B}$ & cyanobacterium Lyngbya majuscula from Hawaiian waters & Kan et al. [41] \\
\hline 8-Epi-malyngamide $\mathrm{C}$ & Floridian marine cyanobacterium Lyngbya majuscula & Kwan et al. $[42,43]$ \\
\hline 2Z-isomalyngamide $\mathrm{K}$ & Papua New Guinea field collection of the cyanobacterium Lyngbya majuscula & Han et al. [44] \\
\hline $\begin{array}{c}\text { Serinol-derived } \\
\text { malyngamide }\end{array}$ & Australian Cyanobacterium & Wan et al. [45] \\
\hline
\end{tabular}

Barton protocol to afford 20. Baeyer-Villiger oxidation of 20 using $m$-CPBA proceeded with excellent selectivity to give phenol ester $\mathbf{2 1}$, which was subsequently hydrolyzed to give cyclopropyl fatty acid $\mathbf{2 2}$. Arndt-Eistert homologation/amidation of acid $\mathbf{2 2}$ afforded racemic grenadamide. To the further study, the author obtained the two enantiomers of grenadamide. Fatty acid $\mathbf{2 2}$ was coupled with Evans' auxiliary and chromatographically separating the diastereomers 23 and 24, which were removed of the auxiliary to give (-)-22 and (+)-22 respectively. Then the enantiomerically pure fatty acids were subjected to the Arndt-Eistert protocol to give (-)-grenadamide and (+)grenadamide.

In 2007, Piva and co-workers reported the synthesis of racemic grenadamide through a sequential cross-metathesis/Simmons-Smith cyclopropanation (Scheme 4) [48]. Cross-metathesis of $\mathbf{2 6}$ with 1-nonene $\mathbf{2 5}$ catalyzed by Grubbs type catalyst $\mathbf{2 7}$ delivered $\mathbf{2 8}$ as mixture of $\mathrm{E}$ and $\mathrm{Z}$ isomers. Then cyclopropanation of the mixture of $\mathbf{2 8}$ afforded grenadamide.

In 2010, Boysen and co-workers reported an asymmetric synthesis of $(+)$-grenadamide, an enantiomer of the natural product (-)-grenadamide (Scheme 5) [49]. The cyclopropyl carboxylic ester $\mathbf{2 9}$ was transformed into the corresponding aldehyde $\mathbf{3 0}$ by reduction with lithium aluminium hydride to alcohol, followed by Swern oxidation. Then aldehyde 30 underwent Wittig olefination to give $\alpha, \beta$-unsaturated ester 31. Reduction of $\mathbf{3 1}$ and followed by hydrolysis afforded acid 32, which was coupled with phenethylamine gave $(+)$-grenadamide.

\subsection{The Synthesis of Serinolamide A}

In 2013, our group reported the first total synthesis of (+)serinolamide $\mathrm{A}$ in nine steps from L-serine with $30 \%$ overall yield (Scheme 6) [50]. The synthesis of (+)- 

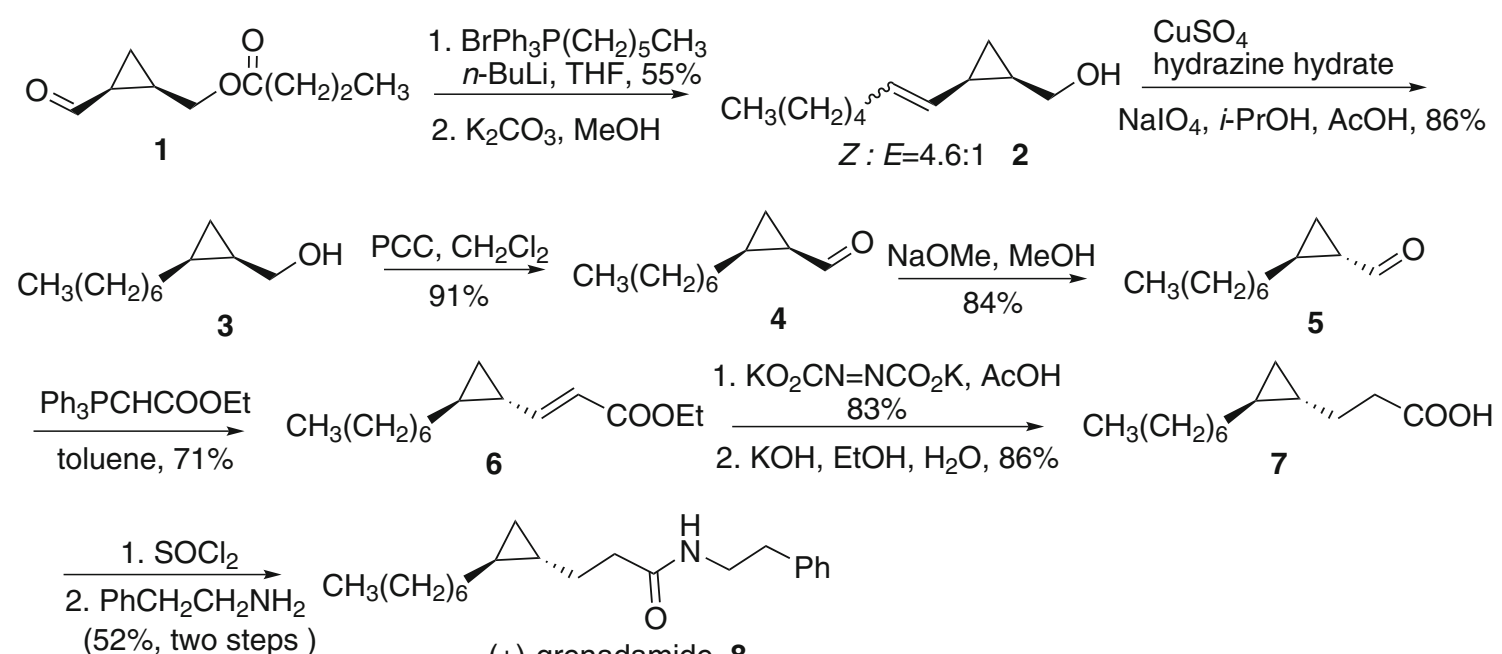

(+)-grenadamide 8

Scheme 1 Synthesis of grenadamide reported by Baird [9]
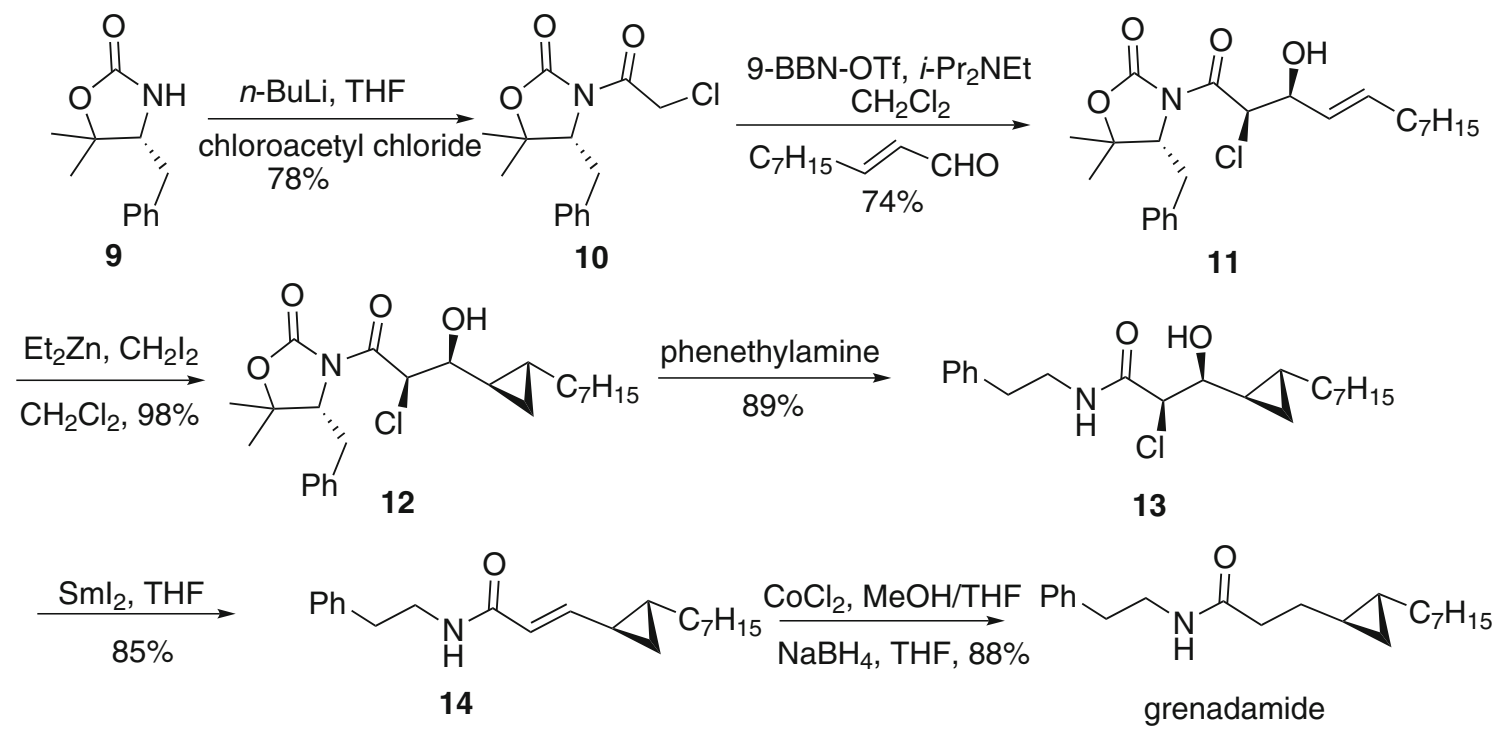

Scheme 2 Synthesis of grenadamide reported by Bull [46]

serinolamide A was divided into two parts, the fatty acid $\mathbf{3 5}$ and the derivatives of serinol $\mathbf{4 0}$ and $\mathbf{4 1}$. The coupling of 1-bromotridecane and pent-4-yn-1-ol using excess $n$-BuLi in HMPA afforded 34. Then reduction of $\mathbf{3 4}$ with $\mathrm{LiAlH}_{4}$ afforded alkene and following oxidation of hydroxyl with PDC gave fatty acid $\mathbf{3 5}$. The other key part was synthesized from L-serine. Esterification of 36, followed by protection of the amino group afforded 37. Methylation of $\mathbf{3 7}$ with iodomethane and then reduction of ether group with $\mathrm{NaBH}_{4}$ gave 38. Protection of the hydroxyl group with TBDMSCl, subsequent $N$-methyl using $\mathrm{MeI}$ and $\mathrm{NaH}$ afforded 39. Deprotection of Boc group gave the mixture of 40 and 41, which without purification and separation condensed with 35 to afford the corresponding products $\mathbf{4 2}$ and serinolamide A. Then $\mathbf{4 2}$ was treated with TBAF to convert into serinoamide A as well.

Later, Pandey and co-workers reported the synthesis of (+)-serinolamide A in 2015 from the starting material of butadiene monoepoxide in five steps with $51 \%$ yield (Scheme 7) [51]. The compound $\mathbf{4 3}$ under the Trost's DyKAT conditions reacted with phthalimide furnished asymmetric allylic alkylation derivative pthaloyl alcohol $\mathbf{4 4}$ in high regio- and enantioselective. Etherification of $\mathbf{4 4}$ with $\mathrm{MeI}$ in presence of $\mathrm{NaH}$ furnished $\mathbf{4 5}$. Cleavage of phthalimide with hydrazine and then protection of the primary amine with $(\mathrm{Boc})_{2} \mathrm{O}$ gave 46. Then oxidative 

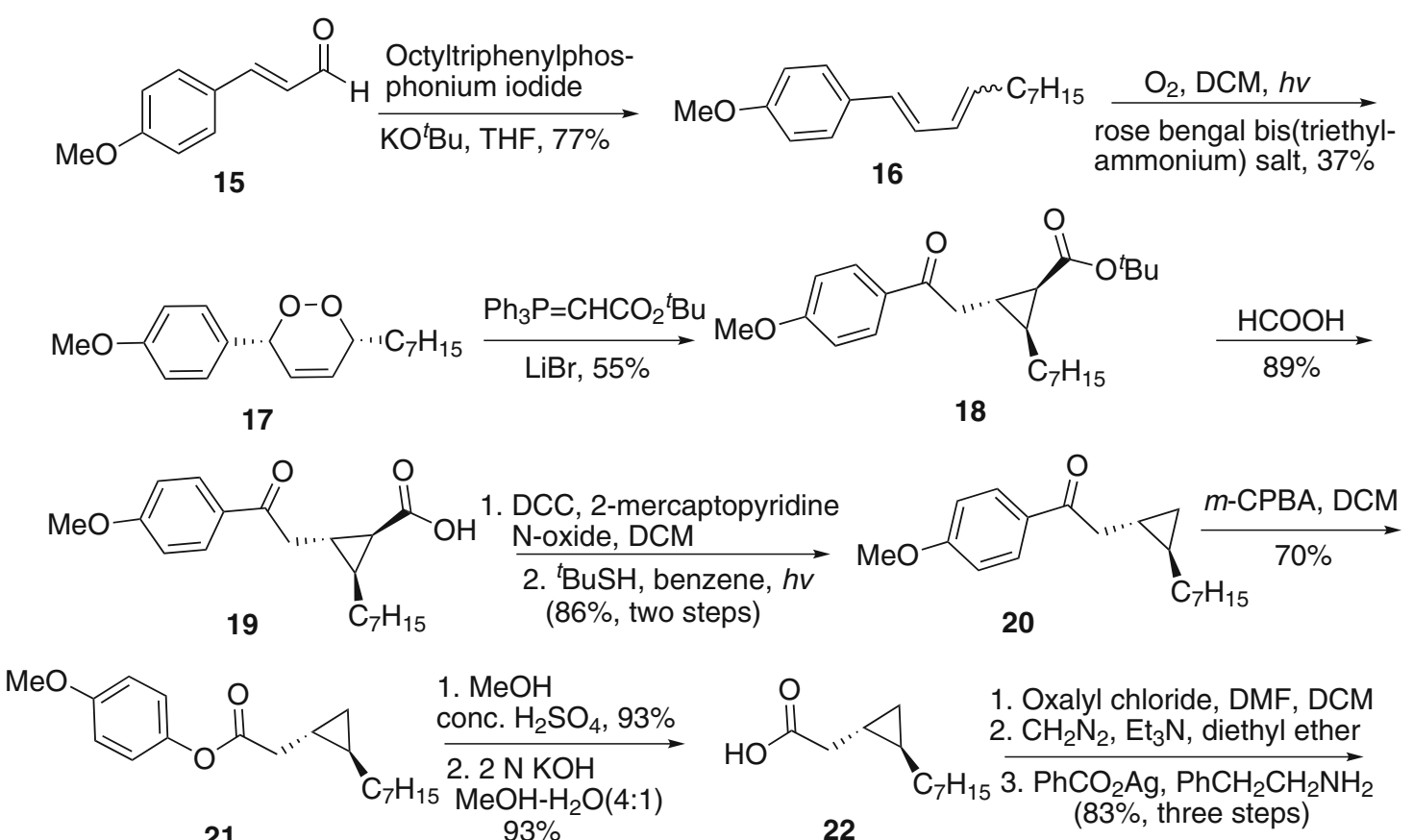<smiles>CCCCC1C[C@@H]1CCC(=O)NCCc1ccccc1</smiles>

grenadamide

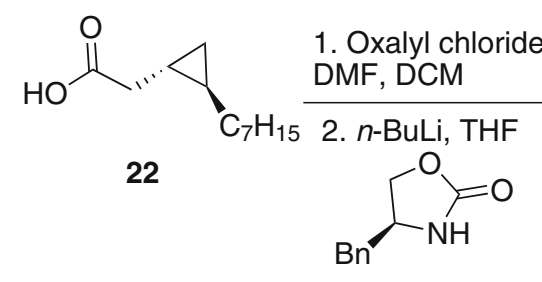

(69\%, two steps)

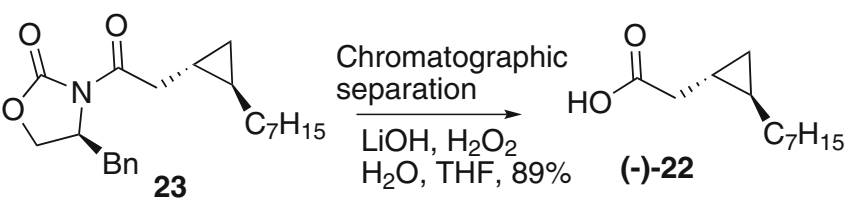<smiles>CC[C@H]1C[C@@H]1CC(=O)O</smiles>

$(+)-22$

Scheme 3 Synthesis of grenadamide reported by Taylor [47]<smiles>C=CCCC(=O)NCCc1ccccc1</smiles>

Scheme 4 Synthesis of grenadamide reported by Piva [48]

cleavage of terminal double bond gave the aldehyde, which was under reduction conditions to afford the serino derivative 41. The other part fatty acid 3 was synthesized from pentadec-1-ene 47 and 4-pentenoic acid 48 undertaken RCM reaction. The fatty acid $\mathbf{3 5}$ was then condensed with serino derivative $\mathbf{4 1}$ to afford serinoamide A. 


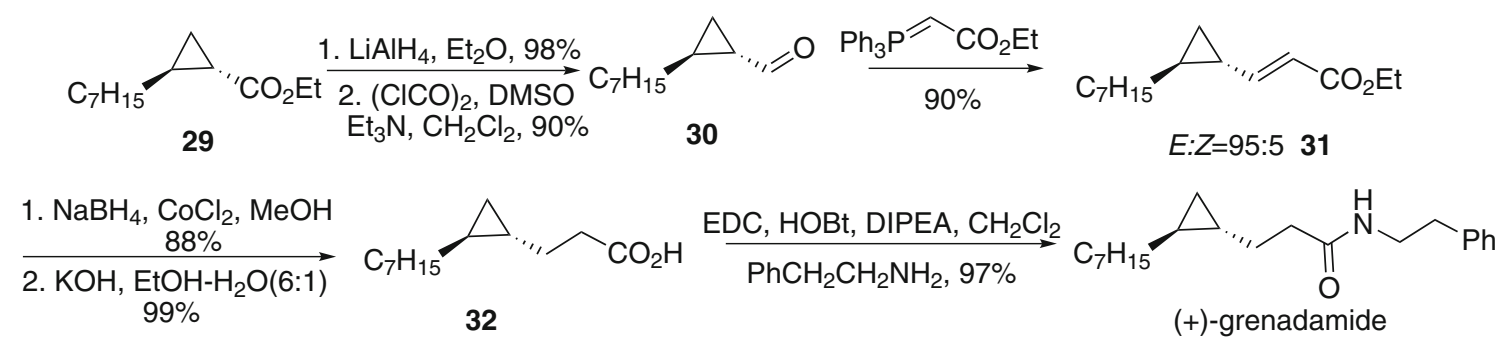

Scheme 5 Synthesis of grenadamide reported by Boysen [49]

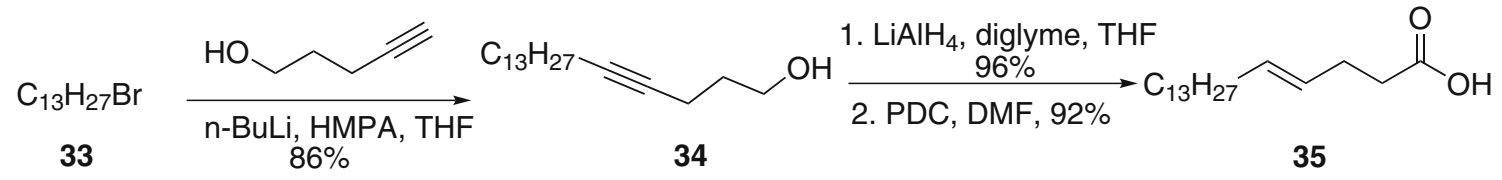

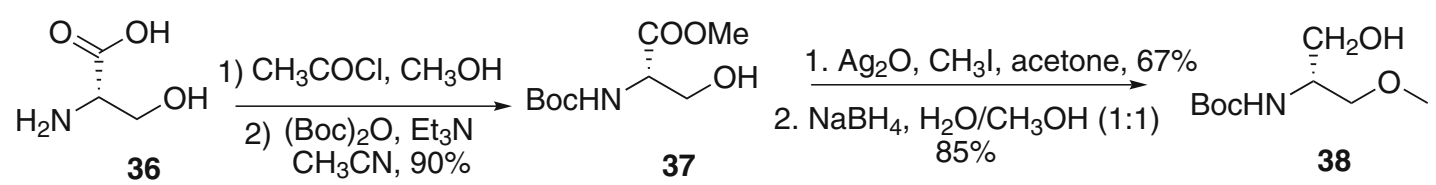<smiles>CN[C@H](CO)COC</smiles>

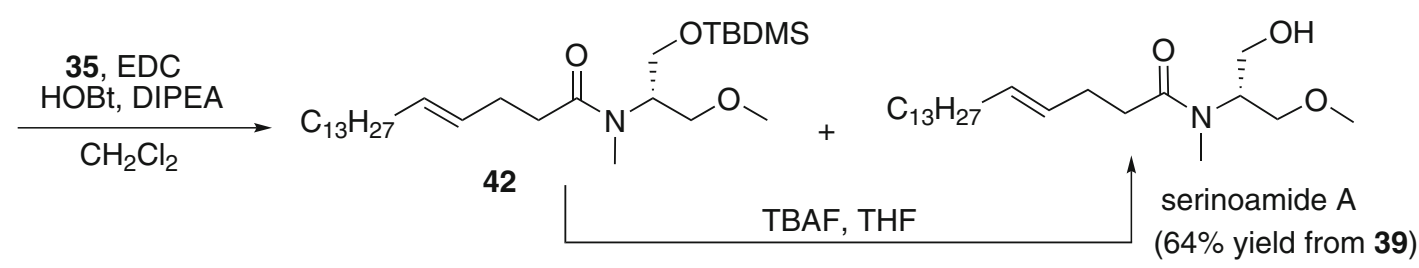

Scheme 6 Synthesis of (+)-serinolamide A reported by Wang [50]

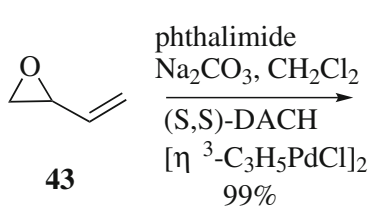<smiles>C=C[C@H](CO)N1C(=O)c2ccccc2C1=O</smiles><smiles>C=C[C@H](COC)N1C(=O)c2ccccc2C1=O</smiles>

$$
\underset{\text { 1. }}{\stackrel{\mathrm{NH}_{2} \mathrm{NH}_{2},\left(\mathrm{CH}_{3}\right)_{2} \mathrm{CH}_{2} \mathrm{OH}}{(\mathrm{Boc})_{2} \mathrm{O}, \mathrm{NaHCO}_{3}}}
$$<smiles>C=C[C@H](COC(=O)O[Na])N[Mg]O[N+](=O)[O-]</smiles>

46<smiles>CN[C@@H](CO)COC</smiles>

41

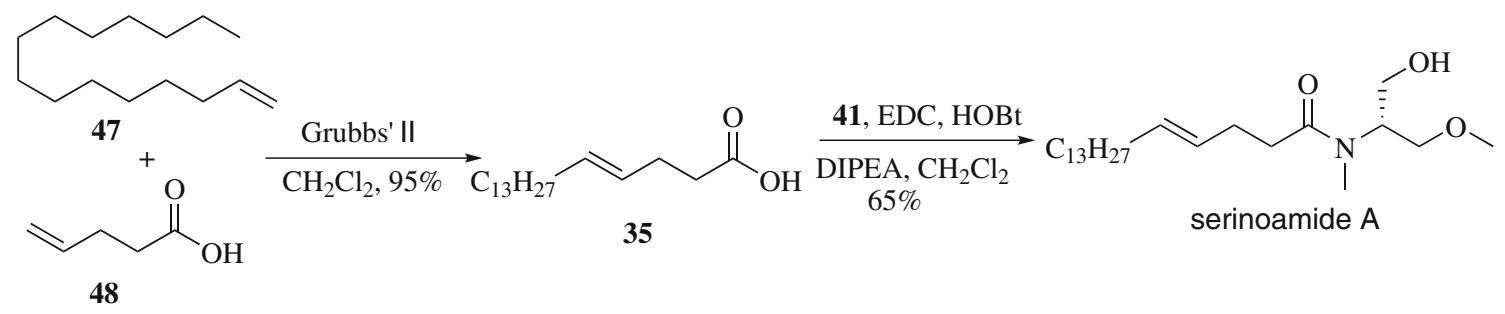

Scheme 7 Synthesis of (+)-serinolamide A reported by Pandey [51] 


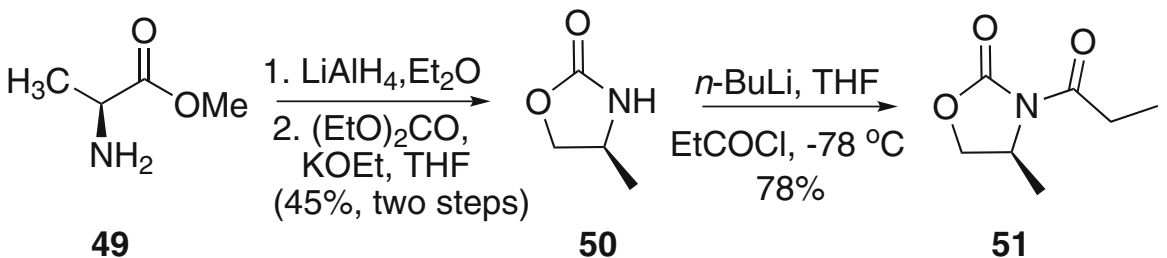

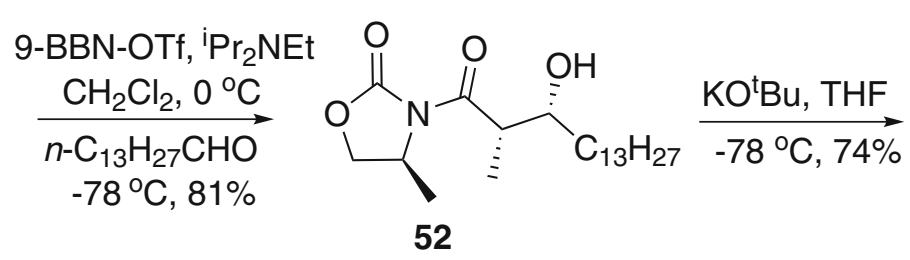

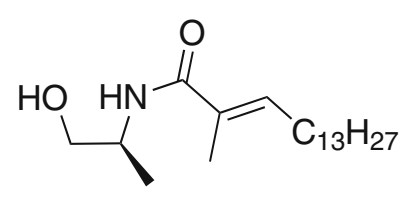

Semiplenamide C

Scheme 8 Synthesis of semiplenamide C reported by Bull [52]<smiles>[R]C(O)C(=C)C(=O)OCC</smiles>

53,54<smiles>[R]C=C(C)C(=O)O</smiles>

$59,84 \%$ yield $60,83 \%$ yield<smiles>[R]C=C(CBr)C(=O)OCC</smiles>

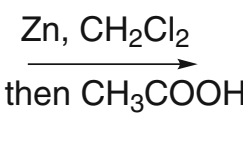

$55,98 \%$ yield $56,98 \%$ yield<smiles>[R]C=C(C)C(=O)OCC</smiles>

$\mathbf{5 7}, 89 \%$ yield $58,87 \%$ yield<smiles>[R]C=C(C)C(=O)N[C@@H](C)CO</smiles><smiles></smiles><smiles>[R]C=C(C)C(=O)N[C@@H](C)COC(C)=O</smiles>

$\mathrm{R}=\mathrm{C}_{15} \mathrm{H}_{31}$, semiplenamide $\mathrm{E}$

for $53,55,57,59$ and $61: \mathrm{R}=\mathrm{C}_{13} \mathrm{H}_{27}, 61=$ semiplenamide $\mathrm{C}$ for $54,56,58,60: R=\mathrm{C}_{15} \mathrm{H}_{31}$

Scheme 9 Synthesis of semiplenamide C reported by Das [53]

\subsection{Synthesis of Semiplenamides}

In 2005, Bull and co-workers developed an efficient method for the synthesis of $(E)-\alpha, \beta$-unsaturated amide and applied the methodology for the synthesis of semiplenamide C (Scheme 8) [52]. L-Alanine methyl ester $\mathbf{4 9}$ was chosen as the starting material. Reduction of $\mathbf{4 9}$ with $\mathrm{LiAlH}_{4}$ and then protection with diethyl carbonate afford 50. Subsequent treatment of $\mathbf{5 0}$ with $n$-BuLi and propionyl chloride gave 51. Then pretreatment of 51 with 9-BBNOTf and $i$ - $\mathrm{Pr}_{2} \mathrm{NEt}$ underwent an aldol reaction with tetradecanal to give $\mathbf{5 2}$ in $>95 \%$ de. Finally, deprotection of $\mathbf{5 2}$ with $\mathrm{KO}^{t} \mathrm{Bu}$ afforded semiplenamide $\mathrm{C}$.

In 2009, Das and co-workers reported the synthesis of semiplenamides $\mathrm{C}$ and $\mathrm{E}$ through the Baylis-Hillman adducts [53]. (Scheme 9) The Baylis-Hillman adducts $\mathbf{5 3}$ and 54 were treated with $\mathrm{PPh}_{3} / \mathrm{CBr}_{4}$ afforded the corresponding allyl bromides 55 and 56, which were subsequently treated with $\mathrm{Zn}$ and $\mathrm{CH}_{3} \mathrm{COOH}$ to give $\mathbf{5 7 , 5 8}$ respectively. The esters $\mathbf{5 7}$ and $\mathbf{5 8}$ were then hydrolyzed with $\mathrm{KOH}$ to give the corresponding acids $\mathbf{5 9}$ and $\mathbf{6 0}$, which were condensed with $(S)$-alaninol to form semiplenamide C (61) and 62 respectively. Compound 62 was further acetylated with acetic anhydride to furnish semiplenamide E.

\subsection{Synthesis of Malyngamides}

In 2006, Piva and co-workers reported both the racemic synthesis and a formal enantioselective synthesis of hermitamides A and B (Scheme 10) [54]. Homoallylic ether 64 was prepared through the Grignard reaction from the octanal 63 and allyl magnesium bromide and the following protection of the hydroxyl group by MeI in the presence of $\mathrm{NaH}$. Then 64 and butenoic acid proceeded RCM reaction to afford 65 with the E/Z ratio of $95 / 5$. Finally, racemic hermitamide $\mathrm{A}$ and $\mathrm{B}$ were synthesized through the condensation of $\mathbf{6 5}$ with the phenethylamine and 3-indolyl- 


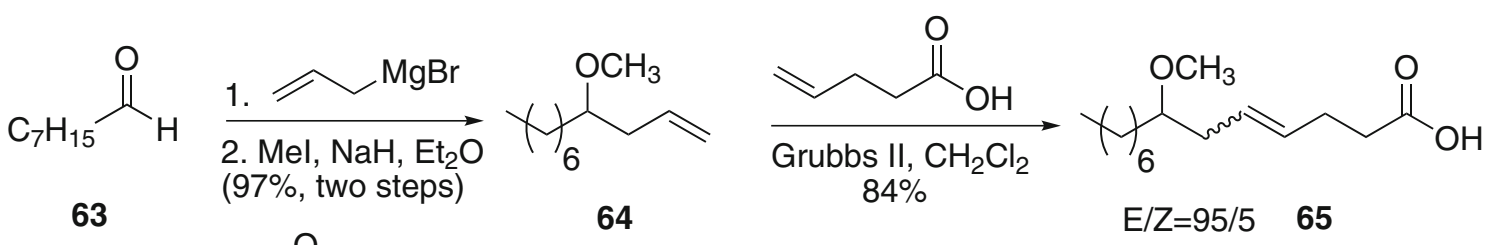

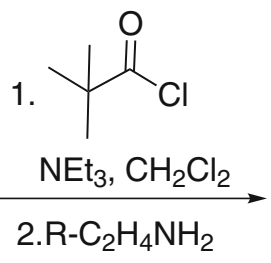<smiles>[R]CCNC(=O)CC/C=C/CC(CCCCCCC)OC</smiles>

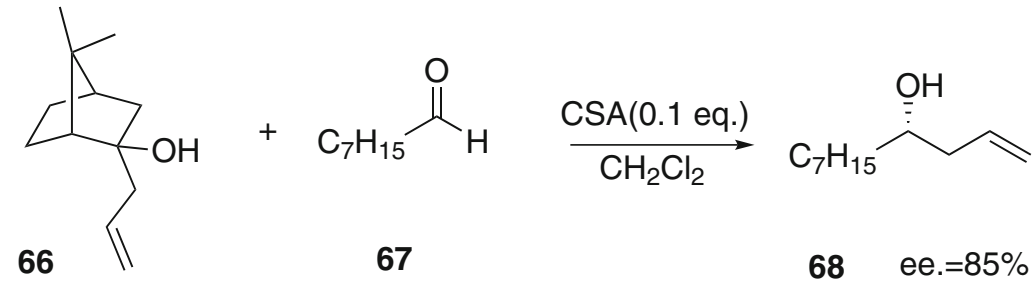

Scheme 10 Synthesis of hermitamides A and B reported by Piva [54]

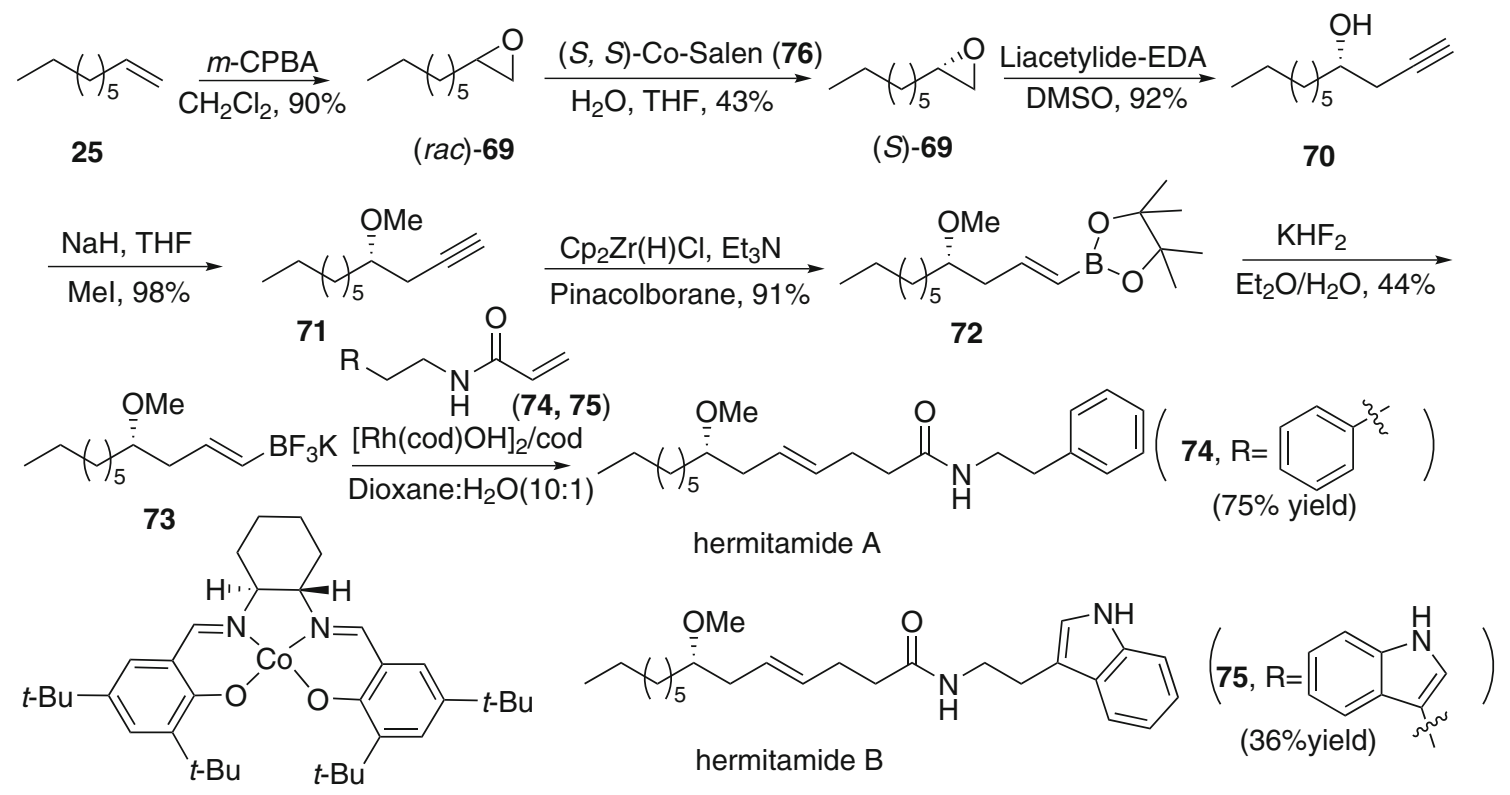

$(S, S)$-Co-Salen (76)

Scheme 11 Synthesis of hermitamides A and B reported by Frost [55]

ethylamine respectively. For the further study, the author developed an enantioselective methodology for the synthesis of $\mathbf{6 8}$, which was obtained through the reaction of (+)-camphor homoallylic alcohol 66 and octanal 67 catalyzed by CAS with the ee value of $85 \%$.

In 2009, Frost and co-workers reported an enantioselective synthesis of hermitamides A and B from the starting material 1-nonene 25 (Scheme 11) [55]. Epoxidation of $\mathbf{2 5}$ by $m$-CPBA afforded the racemic epoxide 69 . Then catalyzed by cobalt (II) complex 76, rac-69 underwent a hydrolytic kinetic resolution process to afford the chiral epoxide $(S)-69$ in $96 \%$ ee. Subsequently, homopropargylic alcohol 70 was obtained when the addition of lithium acetylide complexed with EDA. After methylated the 


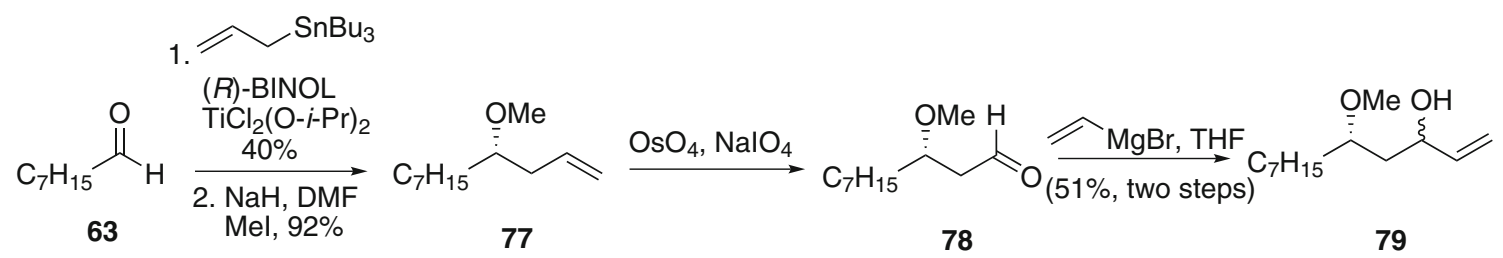

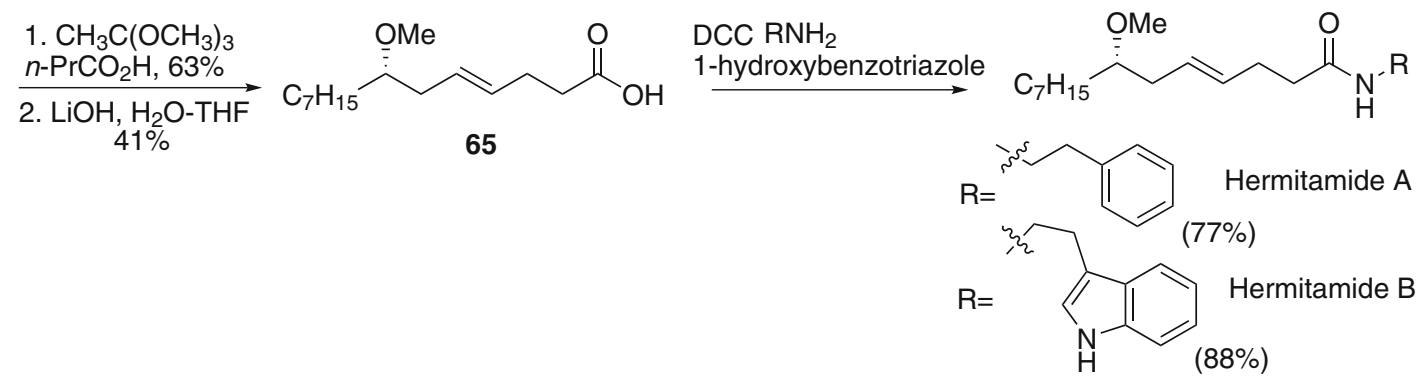

Scheme 12 Synthesis of hermitamides A and B reported by Paige [56]

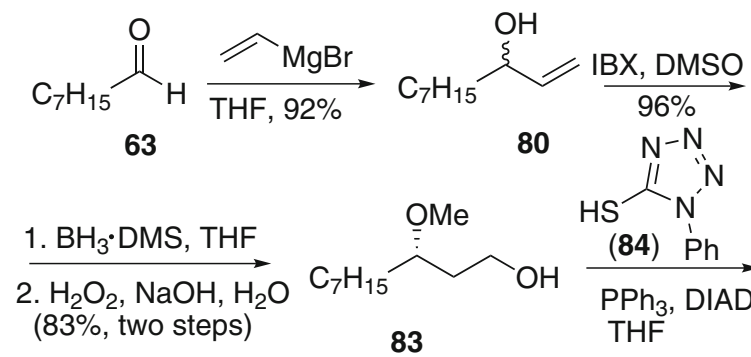

83

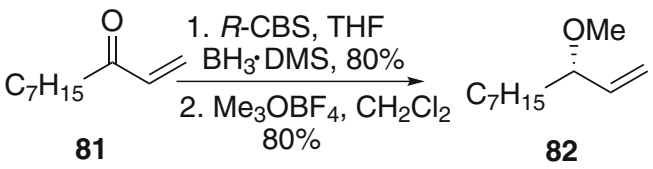<smiles>COC(CCSc1nnnn1-c1ccccc1)CCC(C)C</smiles><smiles>CC[C@H](CCS(=O)(=O)c1nnnn1-c1ccccc1)OC</smiles>

86

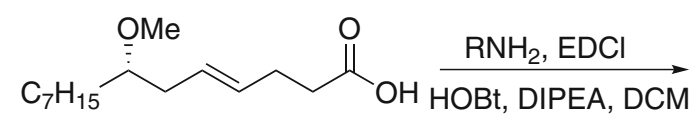

65

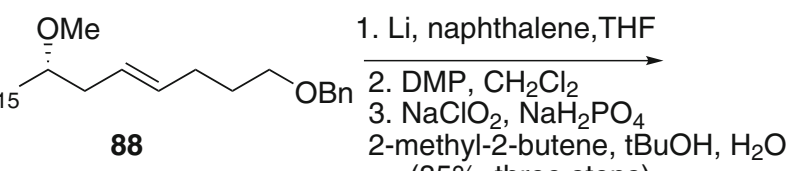
(85\%, three steps)<smiles>[R]NC(=O)CC/C=C/CC(CCCC)OC</smiles>

$\mathrm{R}=2$-phenylethyl, hermitamide $\mathrm{A}$ ( $77 \%$ yield) $\mathrm{R}=3$-indolethyl, hermitamide $\mathrm{B} \quad(75 \%$ yield $)$

Scheme 13 Synthesis of hermitamides A and B reported by Narender [57]

hydroxyl group, the compound $\mathbf{7 1}$ was converted to the chiral alkenylpinacol boronic ester $\mathbf{7 2}$ with the addition of catalytic Schwartz reagent and anhydrous triethylamine. However, 72 was failed to react with both phenylethylamine and tryptamine acrylamide under a range of conditions. Thus pinacolboronic ester $\mathbf{7 2}$ was converted to chiral alkenyltrifluoroborate salt 73. Finally, alkenyltrifluoroborate salt $\mathbf{7 3}$ was reacted with phenylethylacrylamide 74 or 75 in the presence of $[\mathrm{Rh}(\operatorname{cod})(\mathrm{OH})]_{2}$ and cyclooctadiene as the ligand to afford hermitamides $\mathrm{A}$ and $\mathrm{B}$ respectively.

In 2011, Paige and co-workers reported an asymmetric synthesis of hermitamides A and B (Scheme 12) [56].
Asymmetric allylation of octanal with allyltributylstannane mediated by a titanium-binol complex gave homoallylic alcohol followed by the methylation with MeI to afford ether 77. Oxidative cleavage of the terminal double bond yielded aldehyde 78, which was reacted with vinylmagnesiun bromide to afford allylic alcohol 79. The compound 79 was then generated Johnson-Claisen rearrangement with the addition of trimethylorthoacetate in the presence of catalytic amount of propionic acid to afford methyl ester of lyngbic acid followed by the saponification with lithium hydroxide to give $\mathbf{6 5}$. Then acid $\mathbf{6 5}$ was coupled with phenethylamine or tryptamine to afford hermitamides A and $\mathrm{B}$ respectively. 


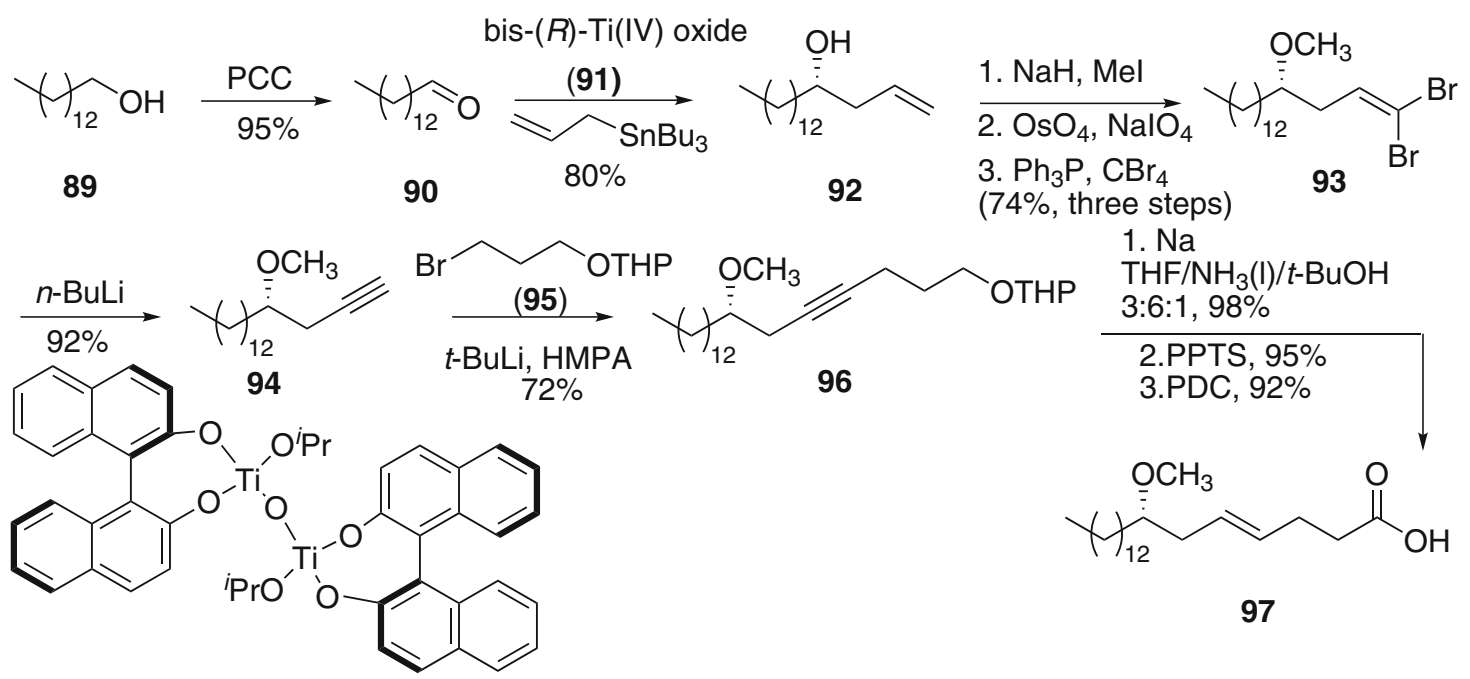

bis- $(R)-\mathrm{Ti}(\mathrm{IV})$ oxide (91)<smiles>NC(CO)C(=O)O</smiles>

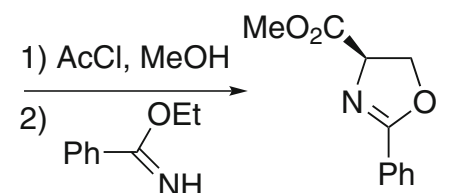

(90\%, two steps)

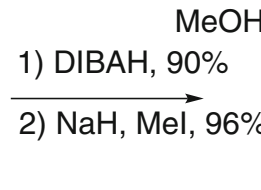

98

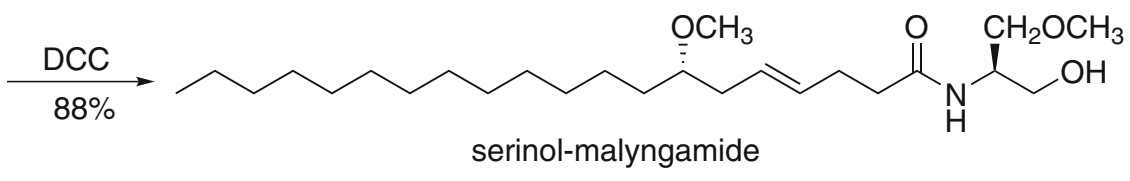

Scheme 14 Synthesis of serinol-malyngamide reported by Cao [58]

In 2014, Narender and co-workers reported a concise total synthesis of hermitamides A and B in a high enantioselectivity (Scheme 13) [57]. The synthesis was commenced from octanal 63. Vinylation with vinyl magnesium bromide gave allylic alcohol $\mathbf{8 0}$, which was oxidated by IBX to afford enone 81. Then asymmetric reduction of ketone $\mathbf{8 1}$ catalyzed by CBS gave the chiral allylic alcohol with high enantioselectivity, which was treated with Meerwein's reagent to afford the methylation product $(S)$ 82. Subsequently, hydroboration-oxidation of $\mathbf{8 2}$ afforded the primary alcohol $\mathbf{8 3}$. Then $\mathbf{8 3}$ with 1 -phenyltetrazole-5thiol (84) underwent Mitsunobu reaction to give aryl sulfide 85, which was further oxidated by ammonium molybdate and hydrogen peroxide to give sulfone $\mathbf{8 6}$. Coupling of alkyl sulfone $\mathbf{8 6}$ with aldehyde $\mathbf{8 7}$ via JuliaLythgoe olefin provided the corresponding olefin $\mathbf{8 8}$ with $E$-geometry exclusively. Then removal of benzyl obtained the primary alcohol following oxidation of the hydroxyl group to furnish lyngbic acid $\mathbf{6 5}$. Acid $\mathbf{6 5}$ was coupled with 2-phenylethyl amine or 3-indolylethylamine to provide hermitamides $\mathrm{A}$ and $\mathrm{B}$, respectively.

In 2006, Cao and co-workers reported the synthesis of serinol-malyngamide for the first time (Scheme 14) [58]. The molecular was divided into two parts, the fatty acid $\mathbf{9 7}$ and the derivative of serinol 100. The stereoselective synthesis of fatty acid $\mathbf{9 7}$ had been reported previous [59], which was starting from 1-tetradecanol. Oxidation of 89 afforded the aldehyde 90, which further reacted with allyltributyltin catalyzed by bis-( $R$ )-Ti(IV) oxide (91) to afford allyl alcohol 92. Methylation of hydroxyl group and followed by oxidation of terminal olefin afforded aldehyde, subsequently reacted with $\mathrm{PPh}_{3} / \mathrm{CBr}_{4}$ to produce dibromide 93. Then alkyne 94 was obtained after the addition of $n$ BuLi. Alkyne coupled with 95 gave 96, reduction of which obtained olefin with $E$-configuration. Sequent deprotection of THP group and oxidation of the obtained primary alcohol afforded fatty acid part 97. The other part of the derivative of serinol $\mathbf{1 0 0}$ would be synthesized from chiral starting material D-serine by the method of Meyers et al. Finally the acid 97 and the derivative of serinol 100 were condensed under the DCC conditions to afford serinolmalyngamide.

In 2007, Isobe and co-workers reported the synthesis of malyngamide $X$ [60], which possessed an unusual tripeptide portion connecting to a methoxylated fatty acyl chain (Scheme 15). Malyngamide X still was divided into two parts tripeptide portion $\mathbf{1 0 8}$ and fatty acid portion $\mathbf{6 5}$. The synthesis of tripeptide portion was started from 


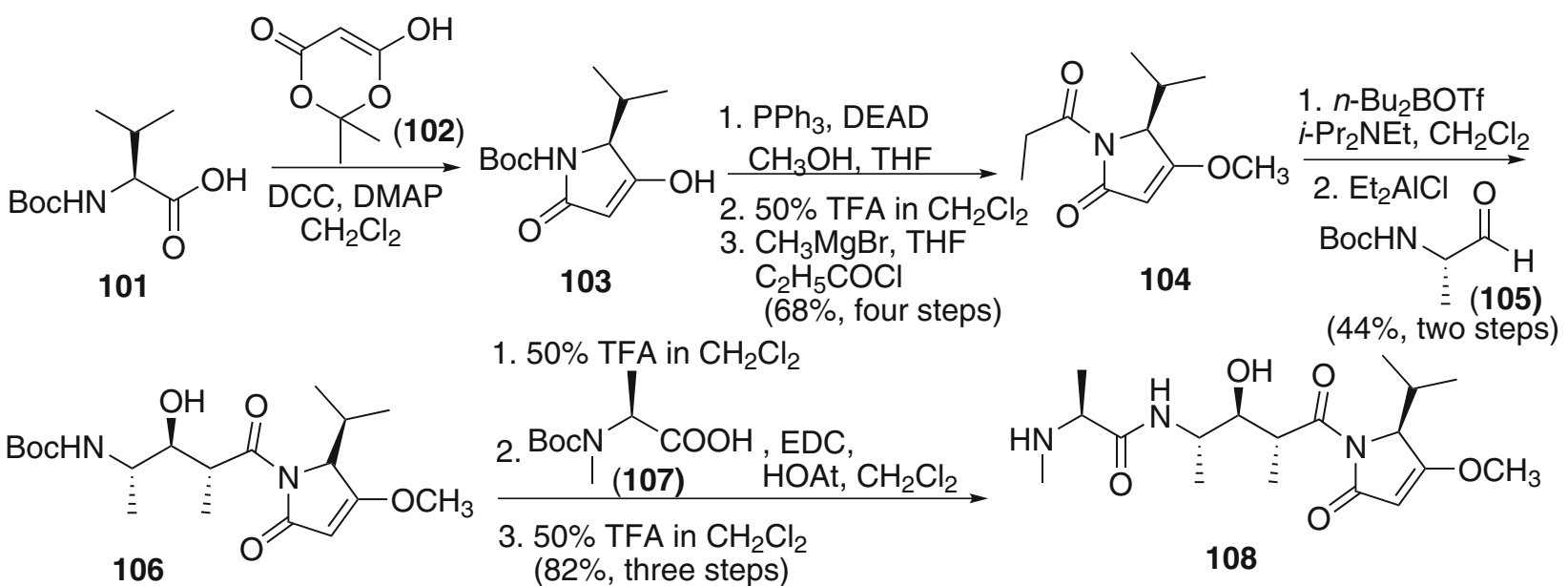
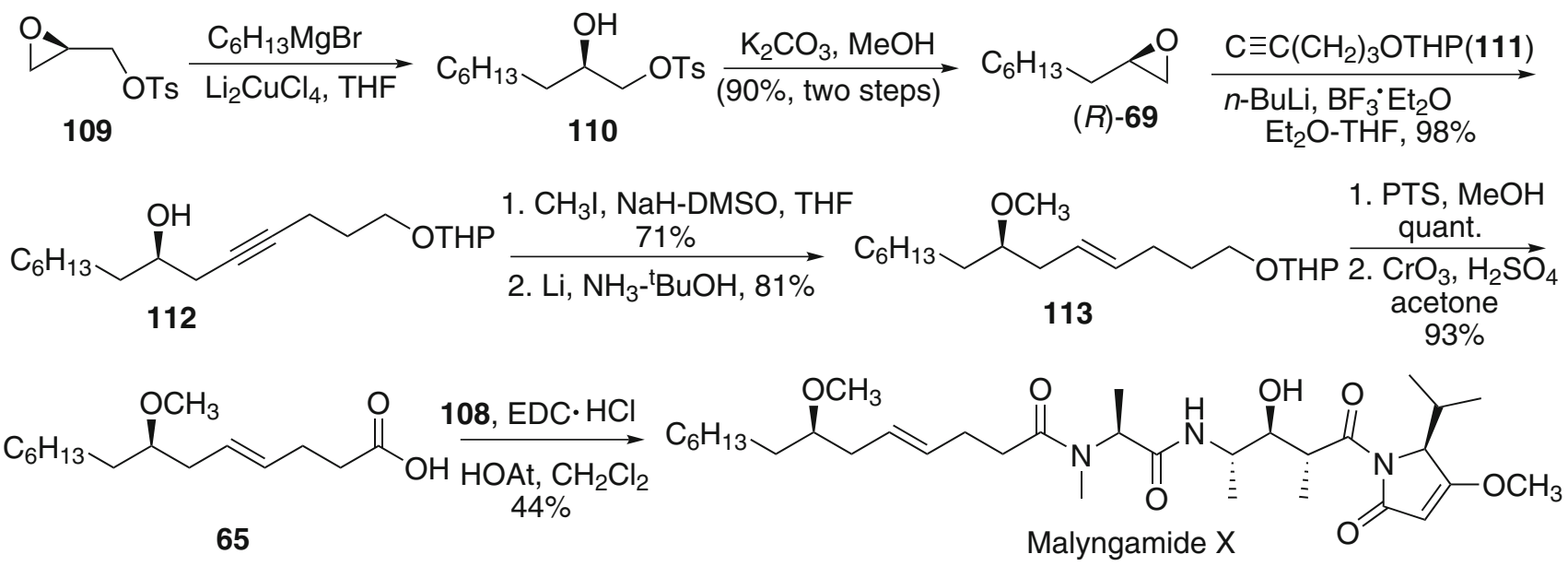

Scheme 15 Synthesis of malyngamide X reported by Isobe [60]

commercially available $N$-Boc-L-valine (101), which was coupled with Meldrum's acid (102) to afford pyrrolidone derivative 103. Then sequent Mitsunobu reaction, deprotection of Boc group and following $N$-propionylation occurred, $N$-propionyl pyrrolidone 104 was obtained. Subsequently, 104 was then coupled with $N$-Boc-L-alaninal (105) assisted by $n$-BuBOTf to afford the pyrrolidone derivative 106. Then the coupling of 106 and Boc- $N$-Me-Lalanine gave the desired tripeptide segment 108. The other part was started from $R$-glycidyl tosylate (109). Thus, Grignard reaction of 109 with $\mathrm{C}_{6} \mathrm{H}_{13} \mathrm{MgBr}$ gave the desired alcohol 110. Then conversion of alcohol 110 to epoxynonane (+)-69 and the following coupling with acetylide 111 gave homopropargylic alcohol 112. Methylation of alcohol and the subsequent reduction of acetylene provided 113 with $E$-geometry. Cleavage of THP protecting group and the following oxidation of hydroxyl group gave fatty acid 65. Finally, coupling of lyngbic acid segment 65 with amine $\mathbf{1 0 8}$ gave malyngamide $\mathrm{X}$.

In 2006, Cao and co-workers reported the total synthesis malyngamide $U$ [61] and revised its correct absolute configuration. The later year, they reported an improved asymmetric synthesis of malyngamide $U$ [62] from the same material and similar methodology (Scheme 16). The fatty acid 114 was synthesized as the same way illustrated in Scheme 13, and the starting material was hexanal instead of tetradecanal. Then amidation of acid 114 with ethanolamine and oxidation of the obtained primary alcohol provided amido-aldehyde 115. The other part started from $(R)-(-)$-carvone 116, which was indicated to convert to $\mathbf{1 2 0}$ for the further aldol reaction with amido-aldehyde 115. Epoxidation of $(R)-(-)$-carvone, reduction of ketone moiety under Luche's conditions and following protection of the hydroxyl group with $p$-methoxybenzyl (PMB) generated 117. Then oxidation of the terminal double bond to ketone and further Baeyer-Villiger rearrangement of ketone with $m$-CPBA gave the corresponding acetate. Removal of acetyl group afforded the secondary alcohol 118. Subsequently the alcohol $\mathbf{1 1 8}$ was protected using allyl bromide and removal of the protecting group PMB with DDQ gave 119. Then the oxidation of the resulted alcohol got ketone by IBX and the reduction of the epoxide 

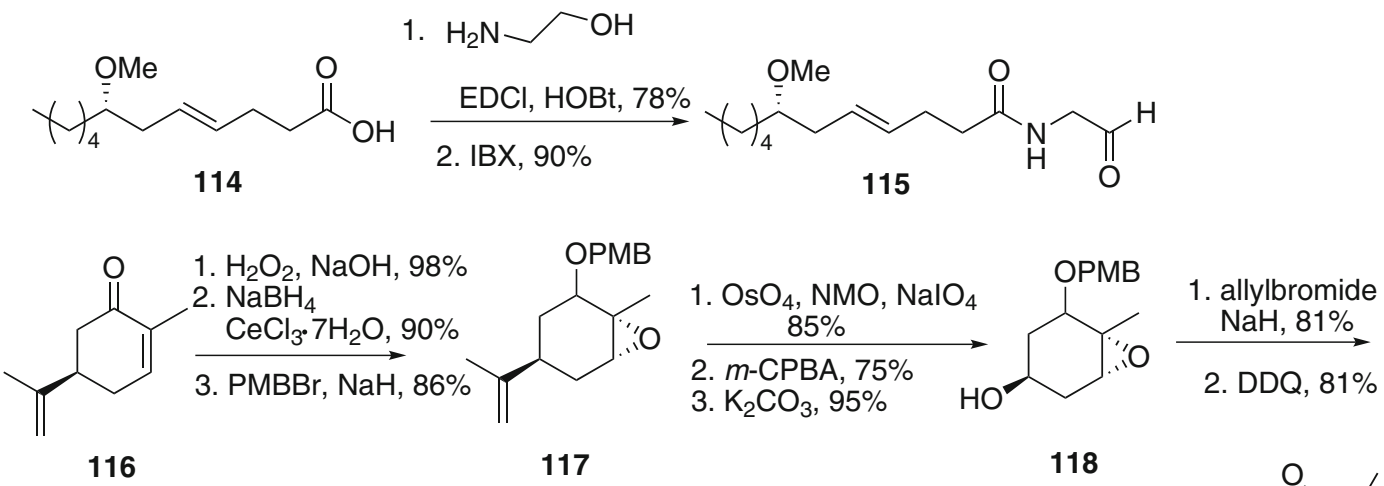

116

117

118

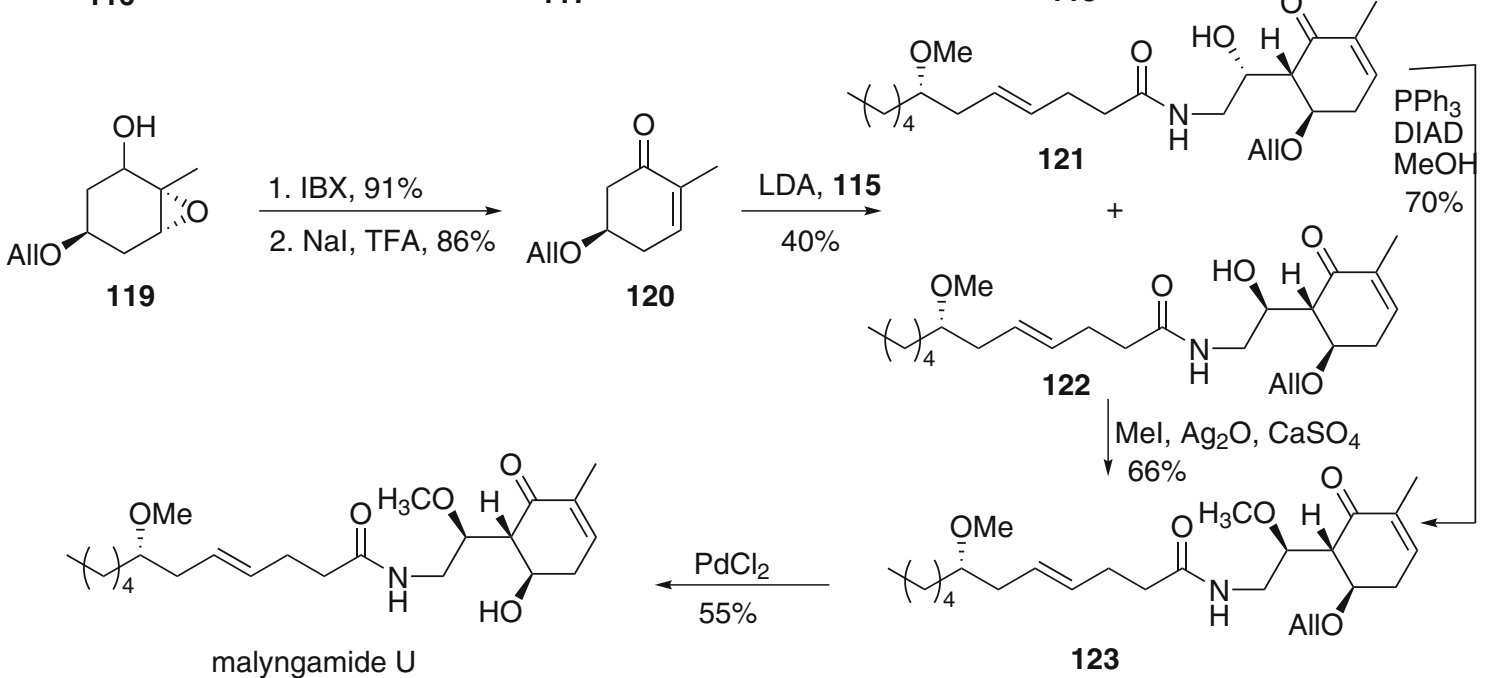

Scheme 16 Synthesis of malyngamide U reported by Cao [62]

on the work of Adams provide the key intermediate $\mathbf{1 2 0}$. Aldol condensation of $\mathbf{1 2 0}$ with amido-aldehyde $\mathbf{1 1 5}$ afforded two epimers 121 and 122. The configuration of 122 was in accordance with malyngamide U. Thus methylation of $\mathbf{1 2 2}$ with MeI gave 123, which was also obtained by Mitsunobu reaction of 121. Finally, removal of the allyl protecting group completed the synthesis of malyngamide $\mathrm{U}$.

In 2009, Cao and co-workers reported a convergent route for the total synthesis of malyngamides $\mathrm{O}, \mathrm{P}, \mathrm{Q}$, and $\mathrm{R}$ (Scheme 17) [63]. Preparation of key intermediate 131 began with ethyl 4-chloro-3-oxobutanoate 124. Azidation of 124 afforded azide 125, which was subsequently hydrogenated by $\mathrm{H}_{2}$ in the presence of di-tert-butyl dicarbonate gave the Boc-protected amine 126. Reduction of both keto and ester carbonyl groups in ester $\mathbf{1 2 6}$ with diisobutylaluminum hydride (DIBAL-H) afforded the corresponding diol, followed by monoprotection of the primary hydroxy group with tert-butyldiphenylsilyl chloride (TBDPSCl) to give the corresponding silyl ether 127. Then oxidation of secondary alcohol $\mathbf{1 2 7}$ with 2-iodoxybenzoic acid (IBX) provided the corresponding ketone 128, which was subjected directly to Wittig olefination with chloromethyltriphenylphosphonium iodide (129) to give the vinyl chloride as a mixture of $Z$ - and $E$-isomers $(\mathrm{Z}: \mathrm{E}=3: 1)$. The Z-configuration of the vinyl chloride was consistent with that in natural malyngamides $\mathrm{O}$ and $\mathrm{P}$. Then $N$-methylation of $\mathbf{1 3 0}$ provided the key vinyl chloride 131. Thus, deprotection of the TBDMS group of $\mathbf{1 3 1}$ with TBAF, followed by oxidation of alcohol with IBX afforded aldehyde 132. Then aldehyde $\mathbf{1 3 2}$ reacted with the enolate derived from methyl acetate in THF to give 133. Racemic alcohol $\mathbf{1 3 3}$ was immediately submitted to deprotection of the Boc group to generate the corresponding amine, which was directly condensed with the carboxylic acid $\mathbf{6 5}$ to afford amide 134. Finally, oxidation of $\mathbf{1 3 4}$ with DessMartin periodinane gave malyngamide P. Deprotionation and the following methylation provided malyngamide $\mathrm{O}$. Then the authors continued to synthesize malyngamides $\mathrm{Q}$ and $\mathrm{R}$, bearing the more challenging structure. The acetamide 138 bearing the pyrrolidone ring was prepared from L-serine 135. Protection of the amino group and hydroxy group in L-serine with $\mathrm{Boc}_{2} \mathrm{O}$ and $\mathrm{TBSCl}$ respectively provided acid 136. Then condensation reaction of $\mathbf{1 3 6}$ with Meldrum's acid, followed by treatment with $\mathrm{MeOH}$ furnished the pyrrodidone intermediate, which was subjected 


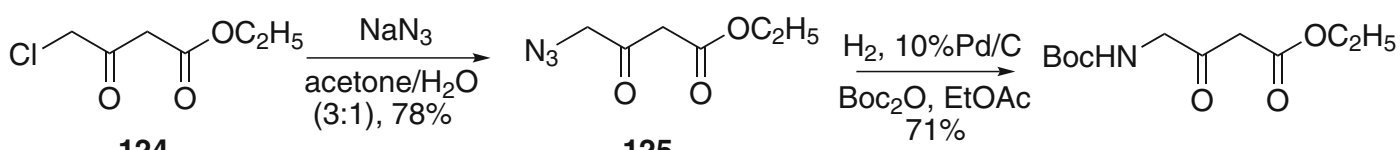

124

125

126

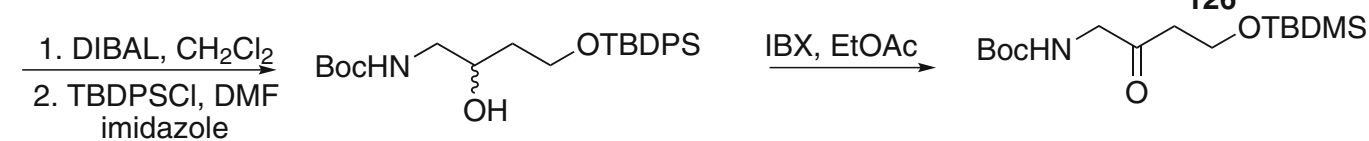

(68\%, two steps)

127

128

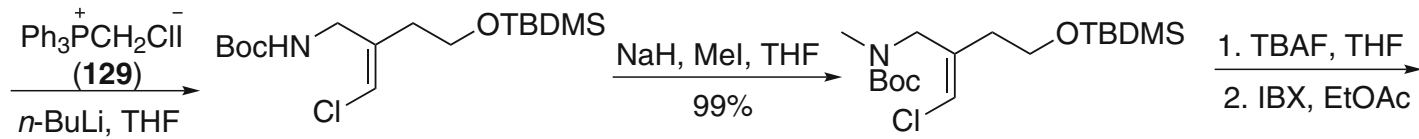

(72\%, two steps)

$130(Z: E=3: 1)$

131

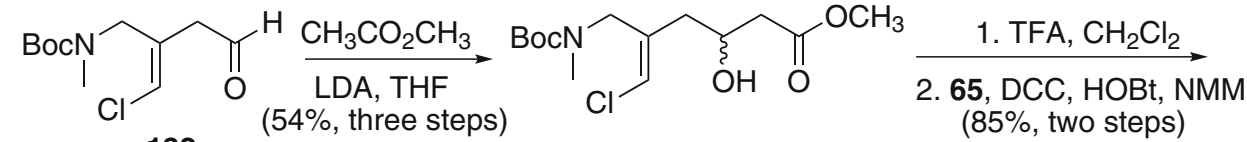

132

(54\%, three steps)

133

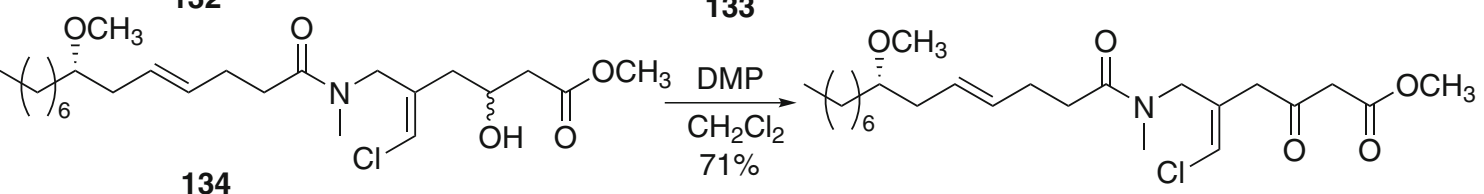

134

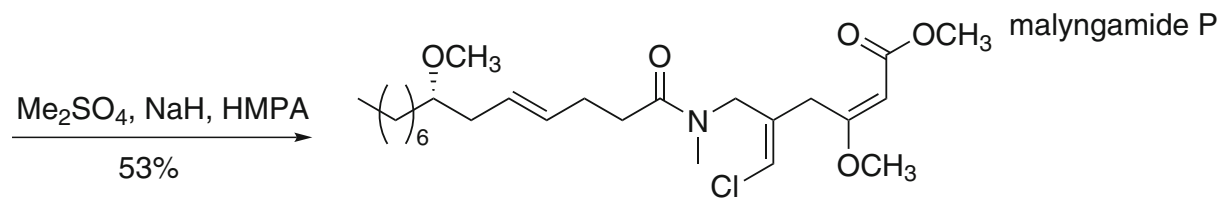

malyngamide $\mathrm{O}$
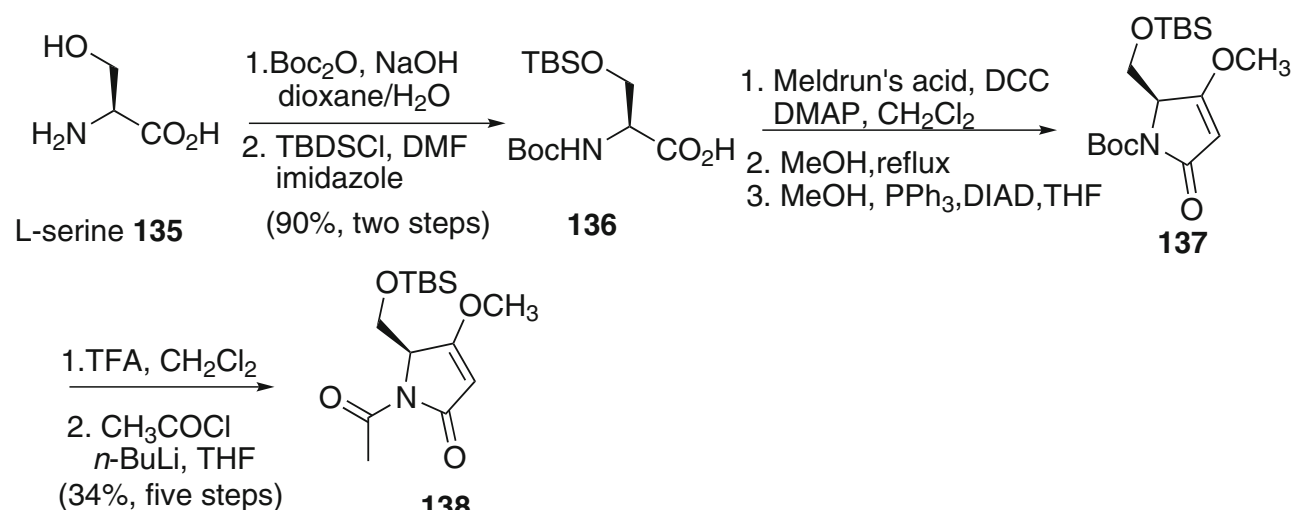<smiles>COC1=CC(=O)N(C(C)=O)[C@H]1Cc1ccccc1OC</smiles>

Scheme 17 Synthesis of malyngamide O, P, Q and R reported by Cao [63]

to a Mitsunobu reaction to give O-methyl pyrrolidone derivative 137. Removal of the Boc group with TFA provided pure amine, which was further protected by acetyl chloride provided $\mathrm{N}$-acetyl pyrrolidone $(S)$-138. However, aldol reaction products of $\mathbf{1 3 8}$ and $\mathbf{1 3 2}$ could be achieved, the further condensation reaction with acid $\mathbf{6 5}$ was failed with little desired compound. Thus another strategy was adopted that was amidation of $\mathbf{1 3 0}$ and $\mathbf{1 3 1}$ first, and then conducted the aldol reaction with $(S)$-138 in the second step. Removal of the Boc groups in 130 and 131, followed by amidation with acid 65 produced amides 141 and 142, respectively. Then deprotection of the TBDMS groups in 141 and 142 with TBAF gave the corresponding alcohols 143 and 144 respectively. $N$-Protection with (Boc) $)_{2} \mathrm{O}$ affored 145. Oxidation of alcohol 144 and 145, followed by condensation precursor enolate of pyrrolidone 138 afforded a diastereomeric mixture of alcohols 146 and 147 respectively. Oxidation of $\mathbf{1 4 6}$ and the following methylation of the enol afforded Malyngamide R. Using the similar route for the preparation of malyngamide $\mathrm{R}$, enol methylation and subsequent removal of the Boc group gave malyngamide Q. 

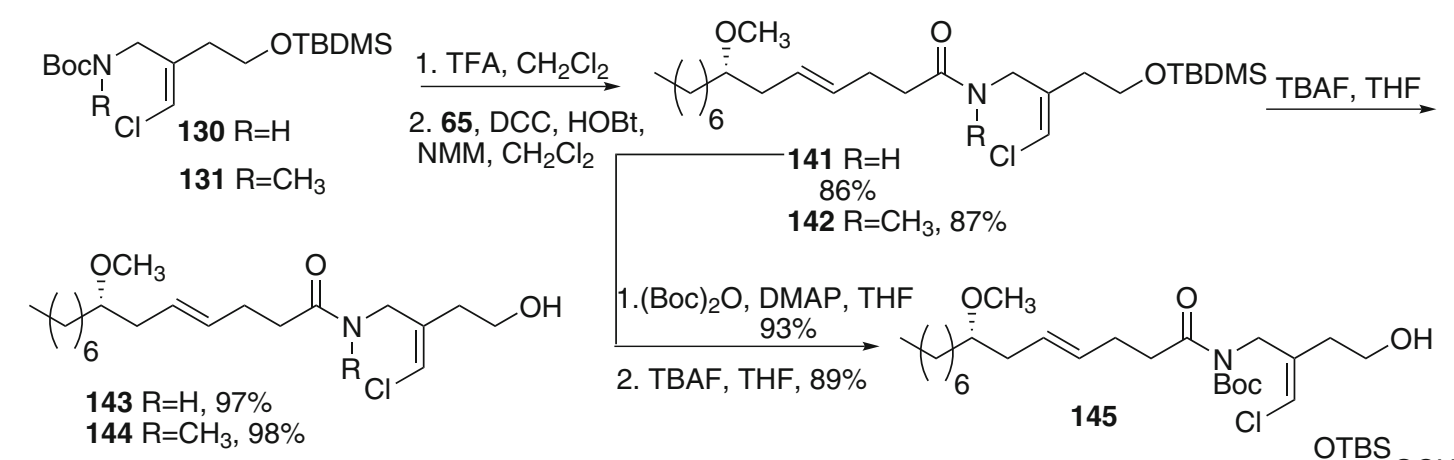

$144 \mathrm{R}=\mathrm{CH}_{3}, 98 \%$
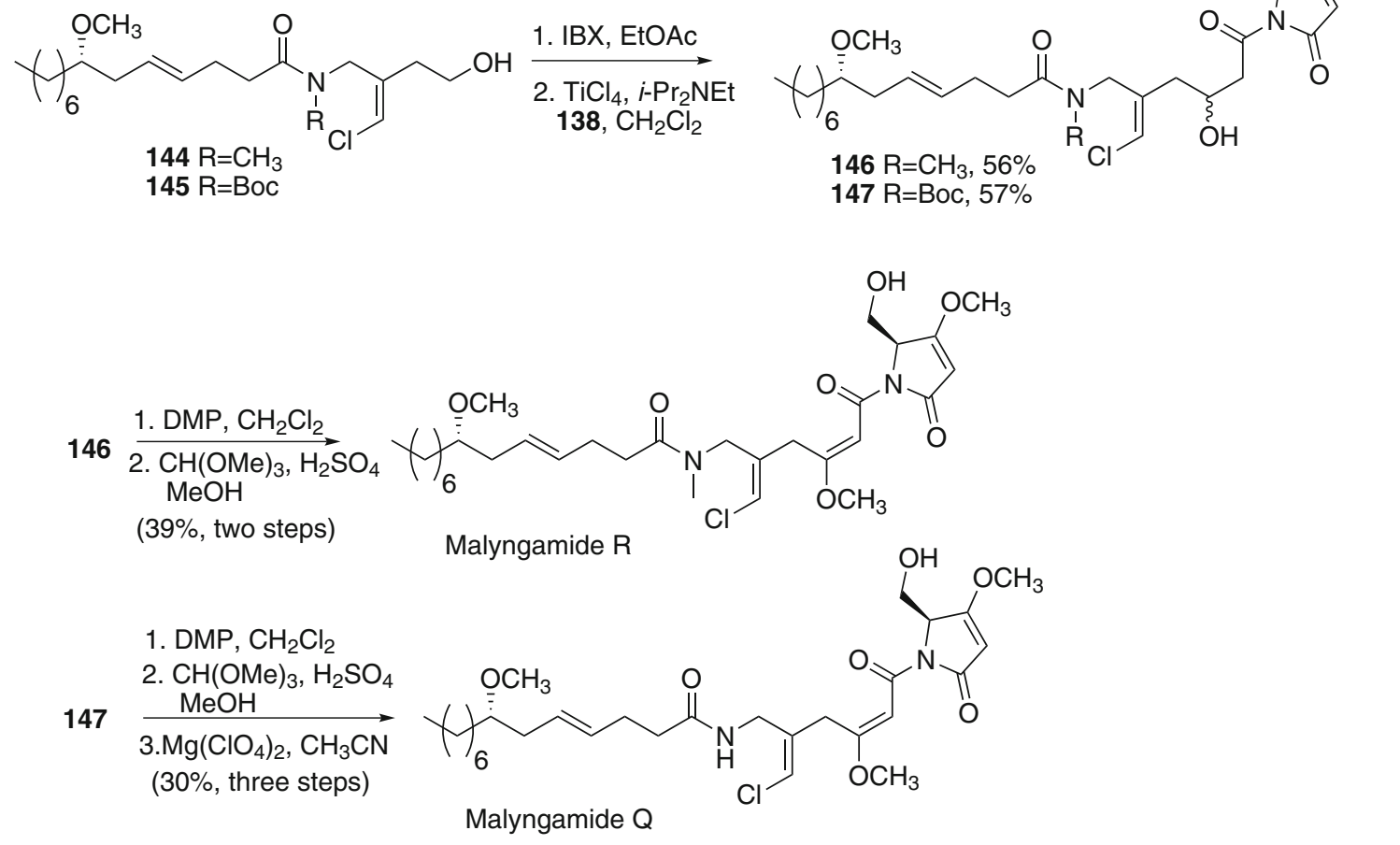

Scheme 17 continued

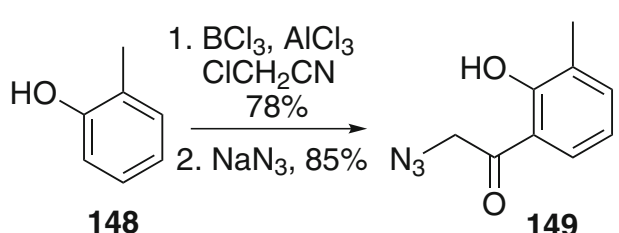<smiles>COc1c(C)cccc1/C(=C/Cl)CNC(=O)OCc1ccccc1</smiles>

151

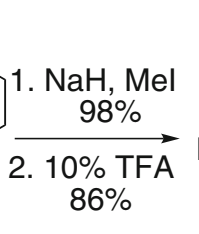

IN<smiles>Cc1cccc(C(=CCl)CI)c1O</smiles>

152

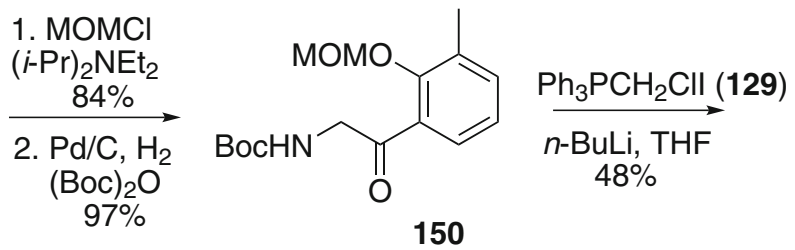

\section{1. $65, \mathrm{DCC}$} HOBt, NMM $83 \%$

2. $300 \mathrm{~nm}$ benzophenone $67 \%$<smiles>CO[C@H](C/C=C/CCC(=O)N(C)C/C(=C/Cl)c1cccc(C)c1O)CC1CC1</smiles>
malyngamide $\mathrm{M}$

Scheme 18 Synthesis of malyngamide M reported by Cao [64]

In 2010, Cao and co-workers reported the stereoselective synthesis of malyngamide M [64], which was still divided into two parts (Scheme 18). The lyngbic acid part 65 was achieved through the common methodology 
reported by their group (Scheme 13). The other amine part 152 possessing a vinylic chloride moiety was synthesized from $o$-cresol 148. Friedel-Crafts acetylation of 148 with chloroacetonitrile and the following substitution reaction with sodium azide gave phenol 149. Then protection of phenol with methoxymethyl chloride and subsequent hydrogenation of azide group by $10 \% \mathrm{Pd} / \mathrm{C}$ in situ protection with di-tert-butyl dicarbonate afforded 150. Then 150 underwent Wittig olefination with chloromethyl triphenylphosphonium iodide to provided $\mathbf{1 5 1}$ with $Z$ geometry. The amine part $\mathbf{1 5 2}$ was obtained through the sequent $N$-methylation and the simultaneous removal of both the MOM and Boc groups. Finally the coupling of acid part $\mathbf{6 5}$ and amine part $\mathbf{1 5 2}$ only afforded the isomalyngamide $\mathrm{M}$ with the $\mathrm{Z}$-vinyl chloride in the structure, which was exposed to UV-light $(\lambda>300 \mathrm{~nm})$ in the presence of benzophenone to afford malyngamide M (Evinyl chloride).

In 2011, Cao and co-workers reported the total synthesis of malyngamide $\mathrm{W}$ and confirmed the absolute configuration of malyngamide $\mathrm{W}$ (Scheme 19) [65]. $\alpha, \beta$-Unsaturated cyclohexanone 155 was a key intermediate towards the synthesis, which was synthesized from $(R)-(-)$-carvone 116. Epoxidation of $\mathbf{1 1 6}$ using hydrogen peroxide provided epoxy ketone 153. Then the epoxide was opened and led to the 3a-hydroxyl ketone. Subsequently, the hydroxy group was further protected by tert-butyldimethylsilyl chloride to provide its TBS-ether 154. Ozonolysis of 154 and subsequent treatment with copper (II) acetate monohydrate/iron sulfate heptahydrate furnished the enone $\mathbf{1 5 5}$. Iodination of 155 obtained $\alpha$-indo- $\alpha, \beta$-unsaturated cyclohexone 156, which underwent Luche's reduction and subsequent protected by benzyl bromide to afford the key iodide 157 . The other part was synthesized from $\mathbf{1 5 8}$, which was oxidized by IBX to provide the aldehyde 159. Then 157 and $\mathbf{1 5 9}$ underwent Nozaki-Hiyama-Kishi coupling reaction to afford 160, which was removed the $N$-protection group and coupled with lyngbic acid 65 to afford amide 161. Oxidation of 161 with Dess-Martin periodinane afforded 162. Reduction of 162 by Corey-Bakshi-Shibata oxazaborolidine (CBS catalyst) and methylation of the hydroxyl group afforded 163. Then removal of the O-Bn protecting<smiles>C=C(C)[C@H]1CC=C(C)C(=O)C1</smiles>

153

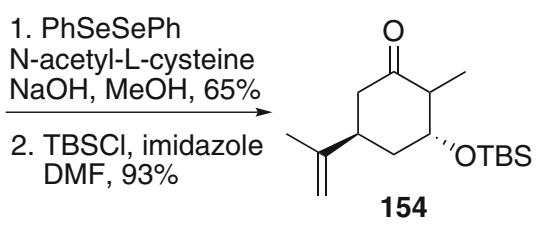

154
1. $\mathrm{O}_{3}$

2. $\mathrm{Cu}(\mathrm{OAc})_{2} \cdot \mathrm{H}_{2} \mathrm{O}$

$\mathrm{FeSO} \cdot 7 \mathrm{H}_{2} \mathrm{O}$

$\mathrm{MeOH} / \mathrm{CH}_{2} \mathrm{Cl}_{2}(2: 1)$

(85\%, two steps)

OBn

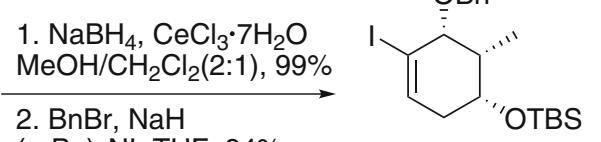

157

$(n-\mathrm{Bu})_{4} \mathrm{NI}, \mathrm{THF}, 94 \%$

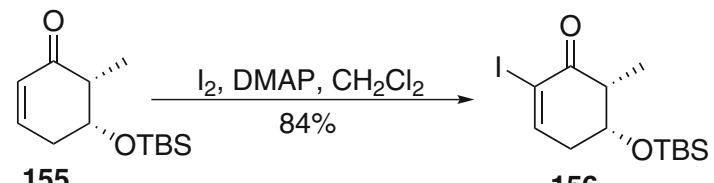
156<smiles>O=C1c2ccccc2C(=O)N1CCO</smiles><smiles>CCOC(=O)O[14C](C)([14CH3])C(=O)O</smiles>

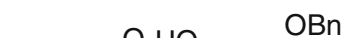
$\mathrm{OBn}$

$$
\begin{aligned}
& \text { 1...' } \mathrm{NH}_{2} \mathrm{NH}_{2}^{\circ} \mathrm{H}_{2} \mathrm{O} \\
& \text { 2, DCC, HOBt } \\
& \text { NMM, } 65 \\
& \text { (80\%, two steps) }
\end{aligned}
$$<smiles>C[C@H]1[C@@H](O)CC=C(C(O)CN)[C@@H]1O</smiles>

161

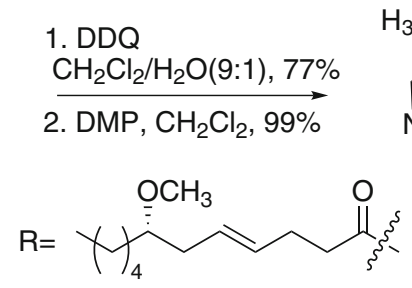

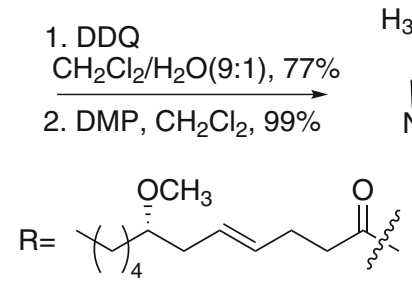

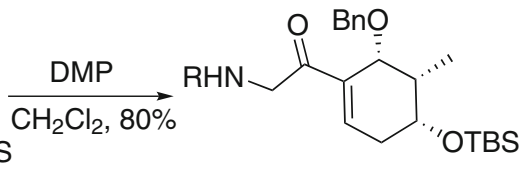

162

$$
\begin{aligned}
& \text { 1. }(R)-\mathrm{CBS}
\end{aligned}
$$

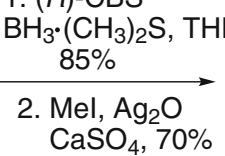

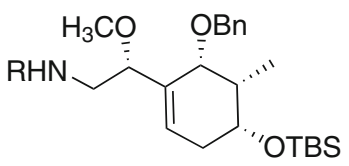

163<smiles>CO[C@@H](CN)C1=CC[C@@H]([OH2+])[C@H](C)C1=O</smiles>
$\underset{\mathrm{TFA} / \mathrm{H}_{2} \mathrm{O}(4: 1)}{\longrightarrow}$ $\mathrm{CH}_{2} \mathrm{Cl}_{2}, 69 \%$ 164

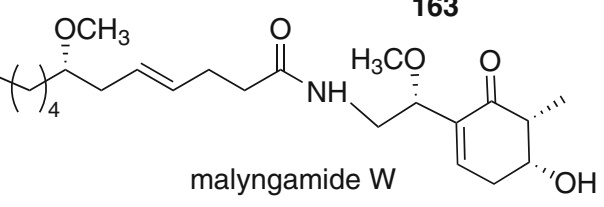

Scheme 19 Synthesis of malyngamide W reported by Cao [65] 


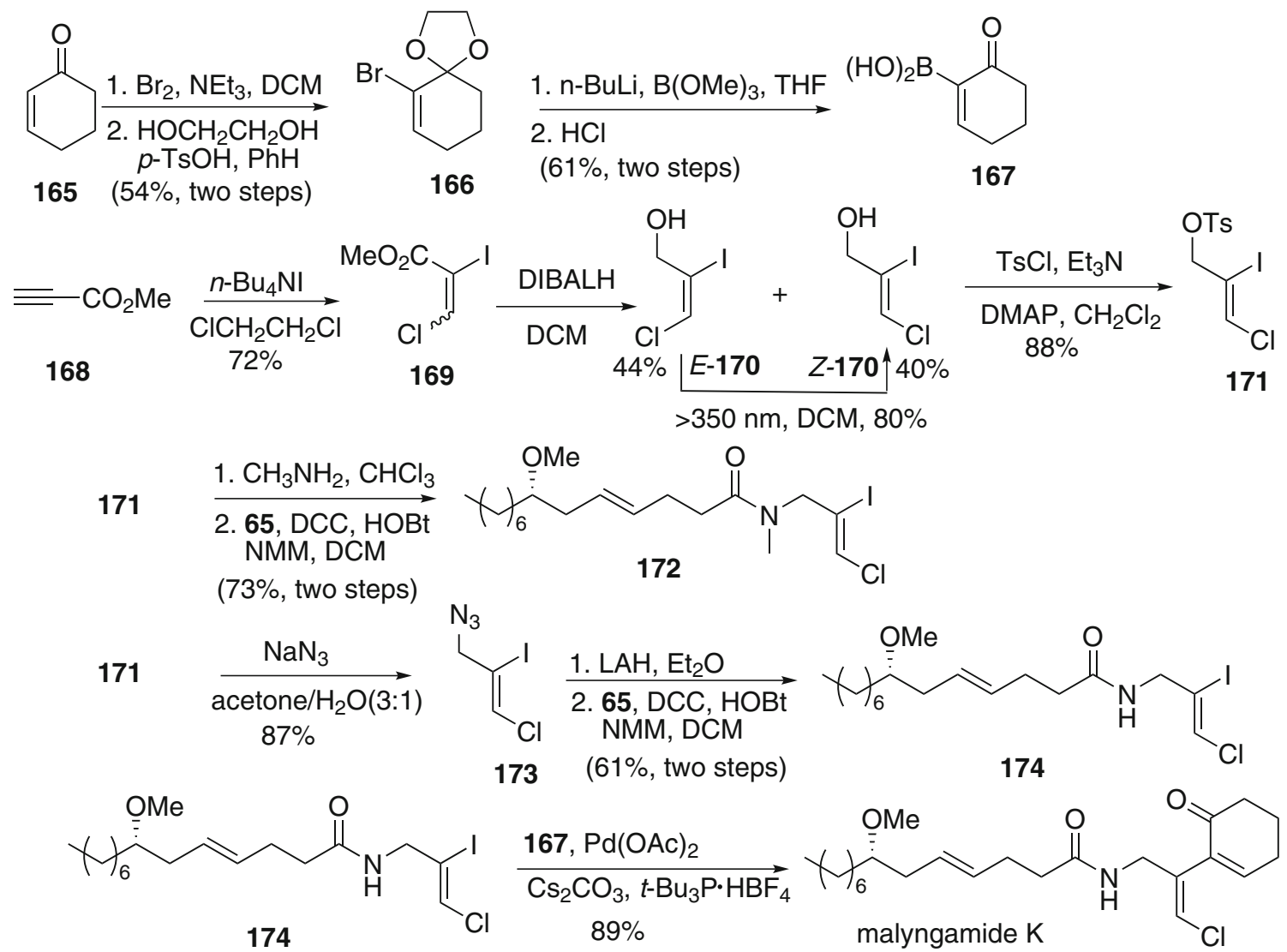

Scheme 20 Synthesis of malyngamide K reported by Cao [66]

group with DDQ and subsequent oxidation of the alcohol with DMP afford amide 164. Finally, removal of the TBS moiety gave malyngamide $\mathrm{W}$.

In 2011, Cao group reported the total synthesis of malyngamides $\mathrm{K}$ (Scheme 20), L, and $5^{\prime \prime}$-epi-C and confirmed absolute configuration of malyngamide L [66]. For the synthesis of malyngamide $\mathrm{K}$, boronic acid part 167 began from 2-cyclohexen-1-one (165). Thus, bromination of enone $\mathbf{1 6 5}$ with bromine generated the bromoenone, followed by protection of the carbonyl group with ethylene glycol to afford the ketal 166. Ketal 166 was easily transformed to boronic acid 167 by treatment with trimethyl borate in the presence of $n$-butyllithium, and subsequent treatment with hydrogen chloride. The other part amides 172 and 174 began with ethyl propiolate 168, which was converted to ester 169 in the presence of $n$-tetrabutylammonium iodide. Then reduction of ester gave the intermediate alcohol $\mathbf{1 7 0}$ as a mixture of $\mathrm{E}$ - and Z-isomers $(\mathrm{E}: Z=1.1: 1)$. The E-isomer could be converted to the desired Z-isomer by irradiation with UV light $(>350 \mathrm{~nm})$ in DCM. Thus, configuration of Z-170 was consistent with that in natural malyngamides $\mathrm{K}, \mathrm{L}$, and epi-C. Then protection of the hydroxyl group with $p$-toluenesulfonyl group afforded the tosylate 171, which was transformed into the intermediates 172 and 174, respectively. The synthesis of amide $\mathbf{1 7 2}$ was also achieved by treatment of tosylate $\mathbf{1 7 1}$ with an excess of aqueous methylamine and followed by amidation with acid $\mathbf{6 5}$. Azidation of $\mathbf{1 7 1}$ and reduction of the obtained azide 173, followed condensation with the acid 65 afforded $\mathbf{1 7 4}$. Then malyngamides $\mathrm{K}$ was achieved by the Suzuki coupling reaction of $\mathbf{1 7 4}$ and $\mathbf{1 6 7}$.

Then the authors completed the more complex malyngamides L, and 5"-epi-C (Scheme 21) [66]. For the synthesis of malyngamides $5^{\prime \prime}$-epi-C, the key was the synthesis of boronic acid part 182. Oxidation of $\mathbf{1 7 5}$ using nitrosobenzene gave the corresponding hydroxylamine, which was reduced to afford a single alcohol under Luche conditions, followed by reductive cleavage of the $\mathrm{N}-\mathrm{O}$ bond to afford diol 176. Then deketalization and elimination of diol $\mathbf{1 7 6}$ with hydrogen chloride in THF/water (1:1) gave enone 177. Protection of the hydroxyl group of $\mathbf{1 7 7}$ with tert-butyldimethylsilyl chloride and followed by bromination of the corresponding silyl ether gave bromoenone 178. Then ketalization of ketone $\mathbf{1 7 8}$ gave $\mathbf{1 7 9}$ and 180. Deprotection of ketal $\mathbf{1 7 9}$ also afforded ketal $\mathbf{1 8 0}$. Then protection of the hydroxyl group of $\mathbf{1 8 0}$ with allyl bromide afforded the allyl ether $\mathbf{1 8 1}$. Then the boronic acid 182 was prepared by a procedure similar to that for the 


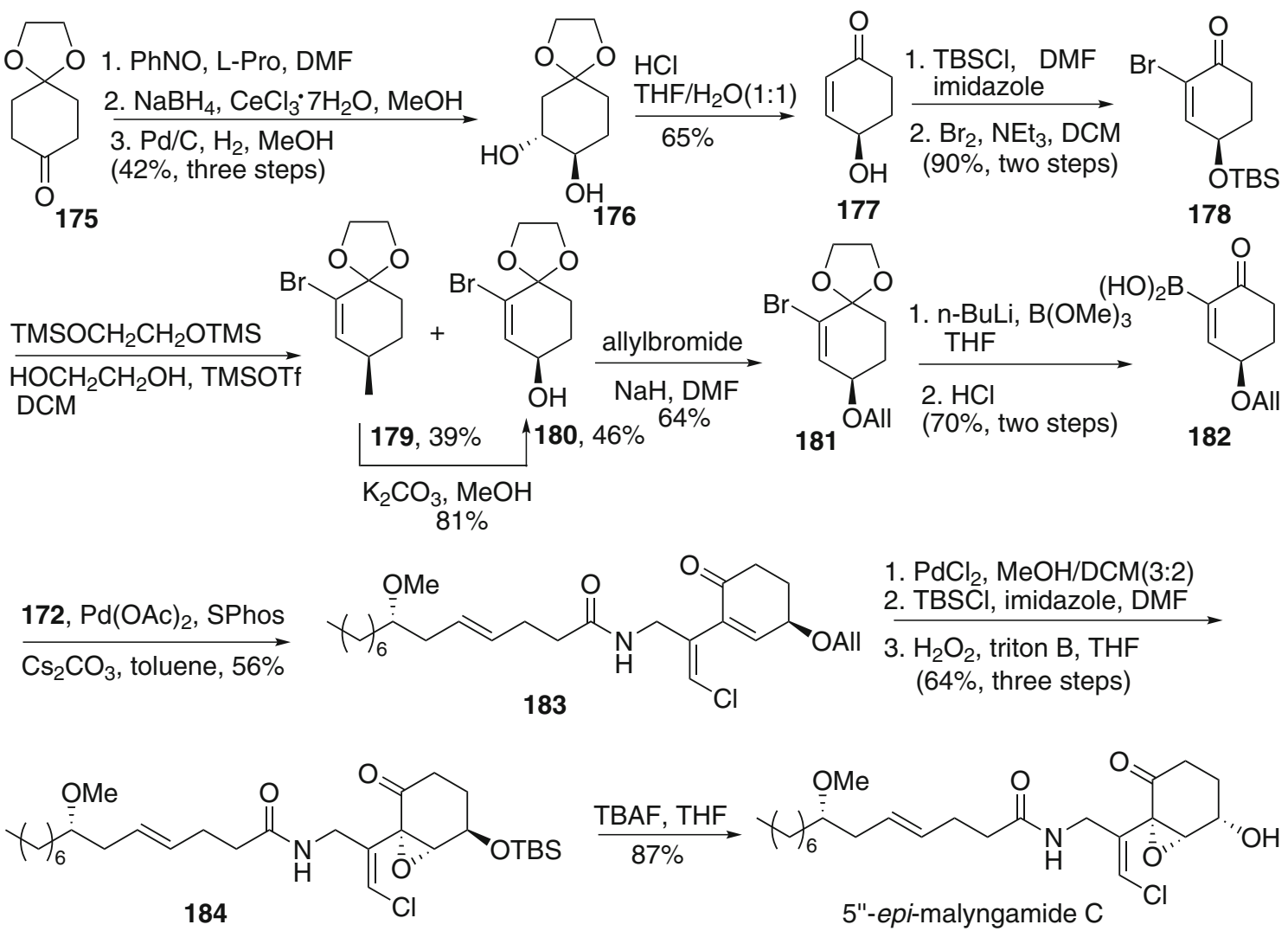

Scheme 21 Synthesis of $5^{\prime \prime}$-epi-malyngamide $\mathbf{C}$ reported by Cao [66]
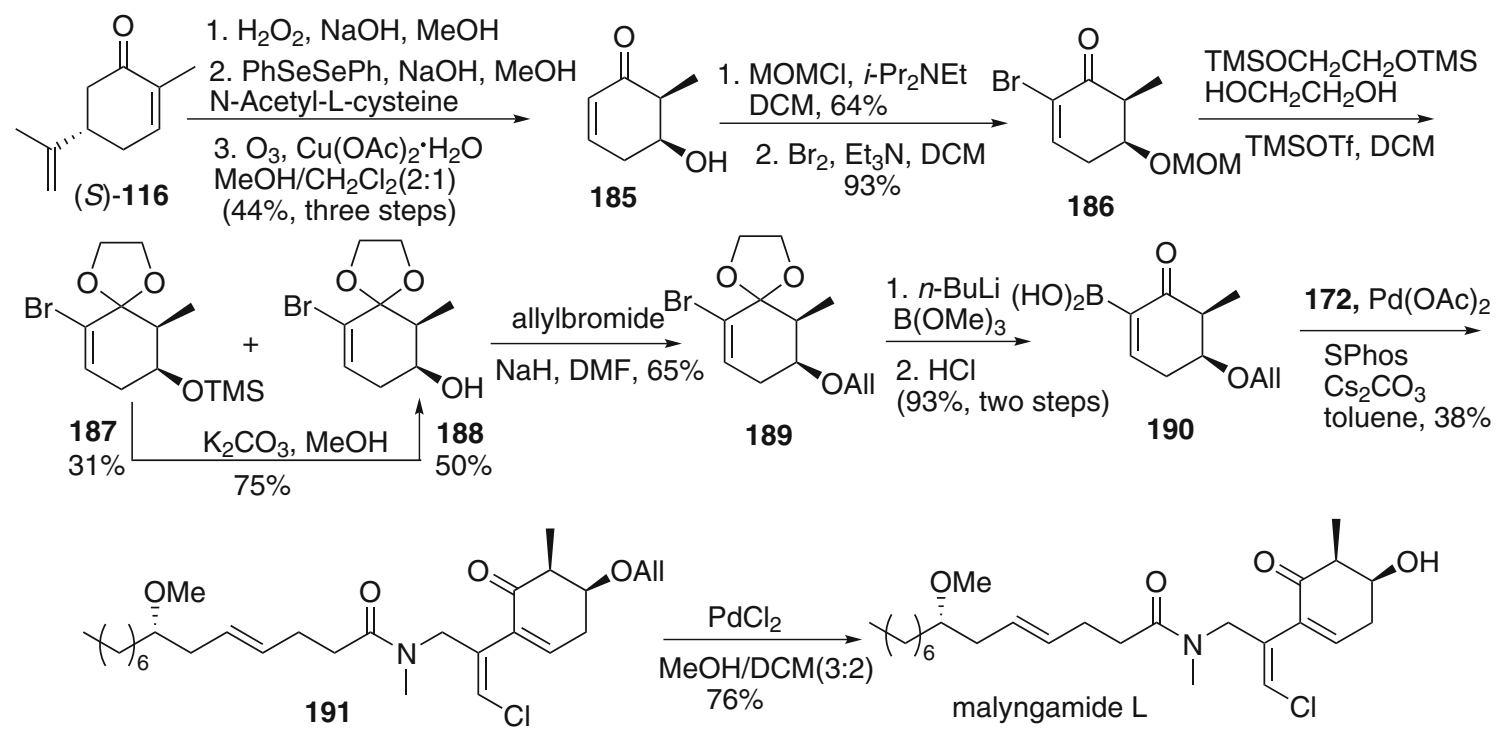

Scheme 22 Synthesis of malyngamide $\mathbf{L}$ reported by Cao [66]

preparation of boronic acid $\mathbf{1 6 7}$. Thus, the skeleton of $5^{\prime \prime}$ epi-malyngamide C could be constructed via Suzuki crosscoupling reaction with 182 and previous prepared 172. Then the allyl ether was converted to silyl ether, followed by stereoselective epoxidation of silyl ether with hydrogen peroxide and benzyltrimethylammonium hydroxide corresponding epoxide 184. Finally, removal of the TBS protecting group with tetrabutylammonium fluoride (TBAF) provided the $5^{\prime \prime}$-epi-malyngamide $\mathrm{C}$, which would be convert to malyngamide $\mathrm{C}$ via the Mitsunobu reaction [42]. 
Then malyngamide $\mathrm{L}$ was prepared via the similar methodology (Scheme 22) [66]. The authors initially began with $(R)-(-)$-carvone, which finally provided $3^{\prime \prime}, 4^{\prime \prime}$-epimalyngamide $\mathrm{K}$. Therefore, $(S)-(-)$-carvone was chosen as the starting material instead. The preparation of the enone 185 underwent a similar sequence showed in Scheme 18 in the preparation of malyngamide $\mathrm{W}$. Then protection of the hydroxyl group of 185 with $\mathrm{MOMCl}$ gave the corresponding ether, followed by bromination to afford the bromoenone 186. Then boronic acid part 190 was prepared through the sequence as the preparation of boronic acid 182. Then Suzuki cross-coupling reaction with 190 and 172 afforded 191, which was removed allyl protecting group to finish malyngamide L.

\section{Conclusion}

This review illustrated a series of lipids which resemble anandamide in structure. At present, only several marine cyanobacterial fatty acid amides have been reported with binding affinities to the cannabinoid receptors, which were grenadamide, mooreamide, semiplenamides $\mathrm{A}, \mathrm{B}$, and $\mathrm{G}$, serinolamides A, B and malyngamide B. Others, due to absence of functional assays test, only have the possibility to interact with $\mathrm{CB}_{1}$ and $\mathrm{CB}_{2}$. Additionally, the metabolites act as receptor agonists implying that they can mediate certain physiological effects through this pathway, which would open more research avenues. Further, a number of total synthesis and well-established synthetic routes have been available; these can assist structural optimization efforts towards more potent analogues, which would be of benefit for understanding the pharmacological mechanisms of cannabinoids and their receptors.

Acknowledgments We are grateful for financial support from National Natural Science Foundation of China (NSFC-21572178 and NSFC-21702162)

\section{Compliance with Ethical Standards}

Conflict of interest The authors declare no conflict of interest.

Open Access This article is distributed under the terms of the Creative Commons Attribution 4.0 International License (http://creative commons.org/licenses/by/4.0/), which permits unrestricted use, distribution, and reproduction in any medium, provided you give appropriate credit to the original author(s) and the source, provide a link to the Creative Commons license, and indicate if changes were made.

\section{References}

1. P. Pacher, S. Bátkai, G. Kunos, Pharmacol. Rev. 58, 389-462 (2006)
2. A.C. Howlett, F. Barth, T.I. Bonner, G. Cabral, P. Casellas, W.A. Devane, C.C. Felder, M. Herkenham, K. Mackie, B.R. Martin, R. Mechoulam, R.G. Pertwee, Pharmacol. Rev. 54, 161-202 (2002)

3. C.G. Stott, G.W. Guy, Euphytica 140, 83-93 (2004)

4. L.A. Matsuda, S.J. Lolait, M.J. Brownstein, A.C. Young, T.I. Bonner, Nature 346, 561-564 (1990)

5. V.D. Marzo, L.D. Petrocellis, Annu. Rev. Med. 57, 553-574 (2006)

6. W.A. Devane, L. Hanus, A. Breuer, R.G. Pertwee, L.A. Stevenson, G. Griffin, D. Gibson, A. Mandelbaum, A. Etinger, R. Mechoulam, Science 258, 1946-1949 (1992)

7. D.M. Lambert, C.J. Fowler, J. Med. Chem. 48, 5059-5087 (2005)

8. V. Di Marzo, T. Bisogno, L. De Petrocellis, D. Melck, B.R. Martin, Curr. Med. Chem. 6, 721-744 (1999)

9. J.R. Al Dulayymi, M.S. Baird, Jones. K. Tetrahedron 60, 341-345 (2004)

10. E. Mevers, T. Matainaho, M. Allara, V.D. Marzo, W.H. Gerwick, Lipids 49, 1127-1132 (2014)

11. M. Gutiérrez, A.R. Pereira, H.M. Debonsi, A. Ligresti, V.D. Marzo, W.H. Gerwick, J. Nat. Prod. 74, 2313-2317 (2011)

12. R. Montaser, V.J. Paul, H. Luesch, ChemBioChem 13, 2676-2681 (2012)

13. B. Han, K.L. McPhail, A. Ligresti, V. Di Marzo, W.H. Gerwick, J. Nat. Prod. 66, 1364-1368 (2003)

14. J.W. Blunt, B.R. Copp, M.H.G. Munro, P.T. Northcote, M.R. Prinsep, Nat. Prod. Rep. 27, 165-237 (2010)

15. M. Nagarajan, V. Maruthanayagam, M. Sundararaman, J. Appl. Toxicol. 32, 153-185 (2012)

16. G.V. Reddy, T.V. Kumar, B. Siva, K.S. Babu, P.V. Srinivas, I. Sehar, A.K. Saxena, J.M. Rao, Med. Chem. Res 22, 4581-4591 (2013)

17. L.T. Tan, T. Okino, W.H. Gerwick, J. Nat. Prod. 63, 952-955 (2000)

18. M.E. Elayshberg, K.A. Blinov, A.J. Williams, E.R. Martirosian, S.G. Molodtsov, J. Nat. Prod. 65, 693-703 (2002)

19. S.G. Molodtsov, M.E. Elyashberg, K.A. Blinov, A.J. Williams, E.E. Martirosian, G.E. Martin, B. Lefebvre, J. Chem. Inf. Comput. Sci. 44, 1737-1751 (2004)

20. J.H. CardellinaII, F. Marner, R.E. Moore, J. Am. Chem. Soc. 101, 240-242 (1979)

21. J.H. Cardellina 11, D. Dalietos, F.-J. Marner, J.S. Mynderse, R.E. Moore, Phytochemistry 17, 2091-2095 (1978)

22. R.D. Ainslie, J.J. Jr Barchi, M. Kuniyoshi, R.E. Moore, J.S. Myndersel, J. Org. Chem. 50, 2859-2862 (1985)

23. J.S. Mynderse, R.E. Moore, J. Org. Chem. 43, 4359-4363 (1978)

24. W.H. Gerwick, S. Reyes, B. Alvarado, Phytochemistry 26, 1701-1704 (1987)

25. F.A. Villa, K. Lieske, L. Gerwick, Eur. J. Pharmacol. 629, 140-146 (2010)

26. A. Praud, R. Valls, L. Piovetti, B. Banaigs, Tetrahedron Lett. 34, 5437-5440 (1993)

27. J. Orjala, D. Nagle, W.H. Gerwick, J. Nat. Prod. 58, 764-768 (1995)

28. J.S. Todd, W.H. Gerwick, Tetrahedron Lett. 36, 7837-7840 (1995)

29. M. Wu, K.E. Milligan, W.H. Gerwick, Tetrahedron 53, 15983-15990 (1997)

30. Y. Kan, T. Fujita, H. Nagai, B. Sakamoto, Y. Hokama, J. Nat. Prod. 61, 152-155 (1998)

31. W.A. Gallimore, P.J. Scheuer, J. Nat. Prod. 63, 1422-1424 (2000)

32. K.E. Milligan, B. Marquez, R.T. Williamson, M. Davies-Coleman, W.H. Gerwick, J. Nat. Prod. 63, 965-968 (2000)

33. D.R. Appleton, M.A. Sewell, M.V. Berridge, B.R. Copp, J. Nat. Prod. 65, 630-631 (2002)

34. L.M. Nogle, W.H. Gerwick, J. Nat. Prod. 66, 217-220 (2003)

35. K.L. McPhail, W.H. Gerwick, J. Nat. Prod. 66, 132-135 (2003) 
36. S. Suntornchashwej, K. Suwanborirux, K. Koga, M. Isobe, Chem. Asian J. 2, 114-122 (2007)

37. O.M. Sabry, D.E. Goeger, W.H. Gerwick, Nat. Prod. Res. 31, 555-561 (2017)

38. K.L. Malloy, F.A. Villa, N. Engene, T. Matainaho, W.H. Gerwick, J. Nat. Prod. 74, 95-98 (2011)

39. S.P. Gunasekera, C.S. Owle, R. Montaser, H. Luesch, V.J. Paul, J. Nat. Prod. 74, 871-876 (2011)

40. L.A. Shaala, D.T.A. Youssef, K.L. McPhail, M. Elbandy, Phytochem. Lett. 6, 183-188 (2013)

41. Y. Kan, B. Sakamoto, T. Fujita, H. Nagai, J. Nat. Prod. 63, 1599-1602 (2000)

42. J.C. Kwan, M. Teplitski, S.P. Gunasekera, V.J. Paul, H. Luesch, J. Nat. Prod. 73, 463-466 (2010)

43. H. Gross, K.L. Mcphall, D.E. Goeger, F.A. Valeriote, W.H. Gerwick, Phytochemistry 71, 1729-1735 (2010)

44. B. Han, U.M. Reinscheid, W.H. Gerwick, H. Gross, J. Mol. Struct. 989, 109-113 (2011)

45. F. Wan, K.L. Erickson, J. Nat. Prod. 62, 1696-1699 (1999)

46. R. Green, M. Cheeseman, S. Duffill, A. Merritt, S.D. Bull, Tetrahedron Lett. 46, 7931-7934 (2005)

47. T.D. Avery, J.A. Culbert, D.K. Taylor, Org. \& Biomol. Chem. 4, 323-330 (2006)

48. H. Salim, O. Piva, Tetrahedron Lett. 48, 2059-2062 (2007)

49. T. Minuth, M.M.K. Boysen, Synthesis 16, 2799-2803 (2010)

50. Y.-R. Gao, S.-H. Guo, Z.-X. Zhang, S. Mao, Y.-L. Zhang, Y.-Q. Wang, Tetrahedron Lett. 54, 6511-6513 (2013)

51. S. Gahalawat, S.K. Pandey, RSC Adv. 5, 41013-41016 (2015)

52. I.R. Davies, M. Cheeseman, D.G. Niyadurupola, S.D. Bull, Tetrahedron Lett. 46, 5547-5549 (2005)
53. B. Das, K. Damodar, N. Bhunia, B. Shashikanth, Tetrahedron Lett. 50, 2072-2074 (2009)

54. M.-A. Virolleaud, C. Menant, B. Fenet, O. Piva, Tetrahedron Lett. 47, 5127-5130 (2006)

55. C.G. Frost, S.D. Penrosea, R. Gleave, Org. Biomol. Chem. 6, 4340-4347 (2008)

56. E.O.D. Oliveira, M.G. Kristin, K.P. Manoj, A. Baheti, K. HyeSik, L.H. MacArthur, S. Dakshanamurthy, K. Wang, L.B. Milton, M. Paige, Bioorganic \& Med. Chem. 19, 4322-4329 (2011)

57. S. Satyanarayana, B.V.S. Reddy, R. Narender, Tetrahedron Lett. 55, 6027-6029 (2014)

58. J. Chen, Y. Li, X.-P. Cao, Tetrahedron Asymmetry 17, 933-941 (2006)

59. Y. Li, J. Chen, X.P. Cao, Synthesis 2, 320-324 (2006)

60. S. Suntornchashwej, K. Suwanboriruxb, M. Isobe, Tetrahedron 63, 3217-3226 (2007)

61. Y. Li, J.P. Feng, W.H. Wang, J. Chen, X.P. Cao, J. Org. Chem. 72, 2344-2350 (2007)

62. J.P. Feng, Z.F. Shi, Y. Li, J.T. Zhang, X.L. Qi, J. Chen, X.P. Cao, J. Org. Chem. 73, 6873-6876 (2008)

63. J. Chen, X.G. Fu, L. Zhou, J.T. Zhang, X.L. Qi, X.P. Cao, J. Org. Chem. 74, 4149-4157 (2009)

64. J. Chen, Z.F. Shi, L. Zhou, A.L. Xie, X.P. Cao, Tetrahedron 66, 3499-3507 (2010)

65. J.-T. Zhang, X.-L. Qi, J. Chen, B.-S. Li, Y.-B. Zhou, X.-P. Cao, J. Org. Chem. 76, 3946-3959 (2011)

66. X.L. Qi, J.T. Zhang, J.P. Feng, X.P. Cao, Org. Biomol. Chem. 9, 3817-3824 (2011) 